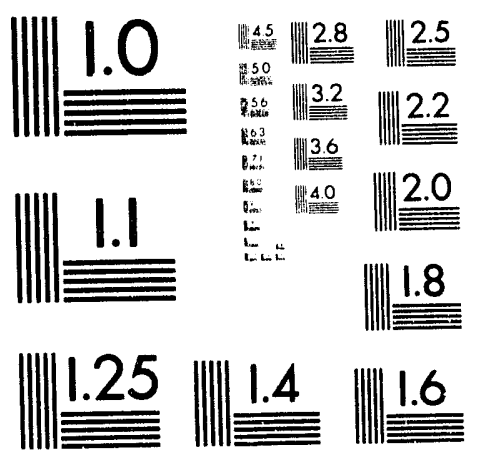



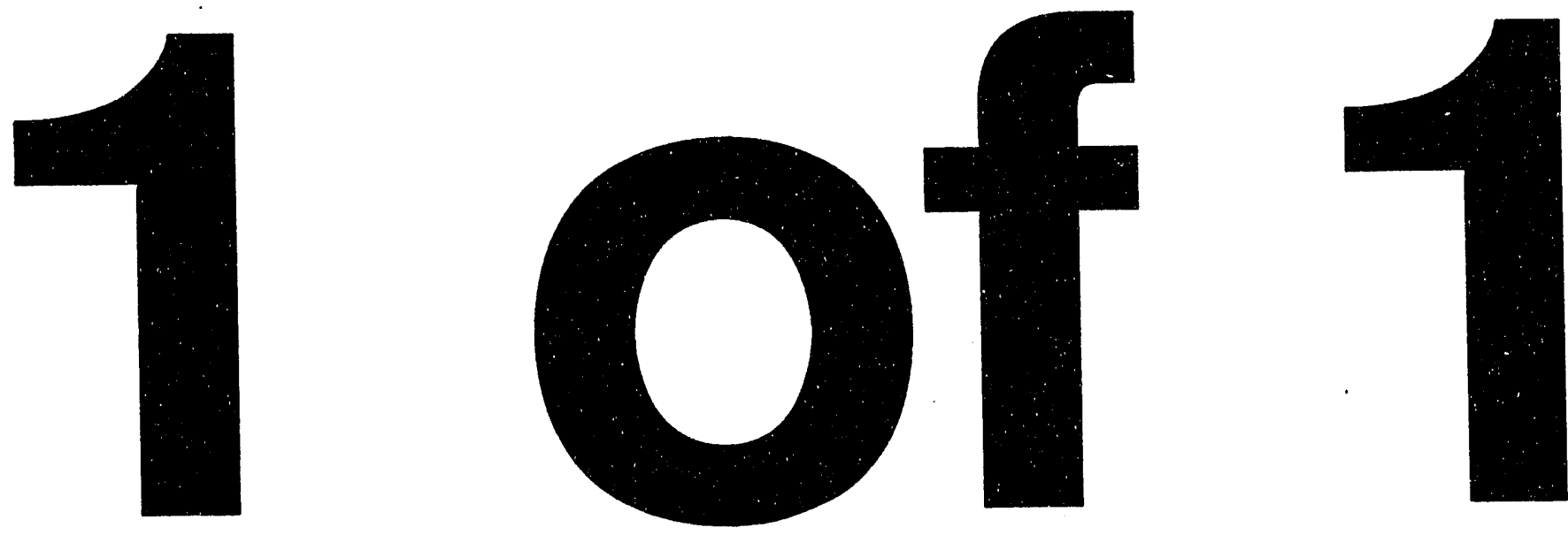


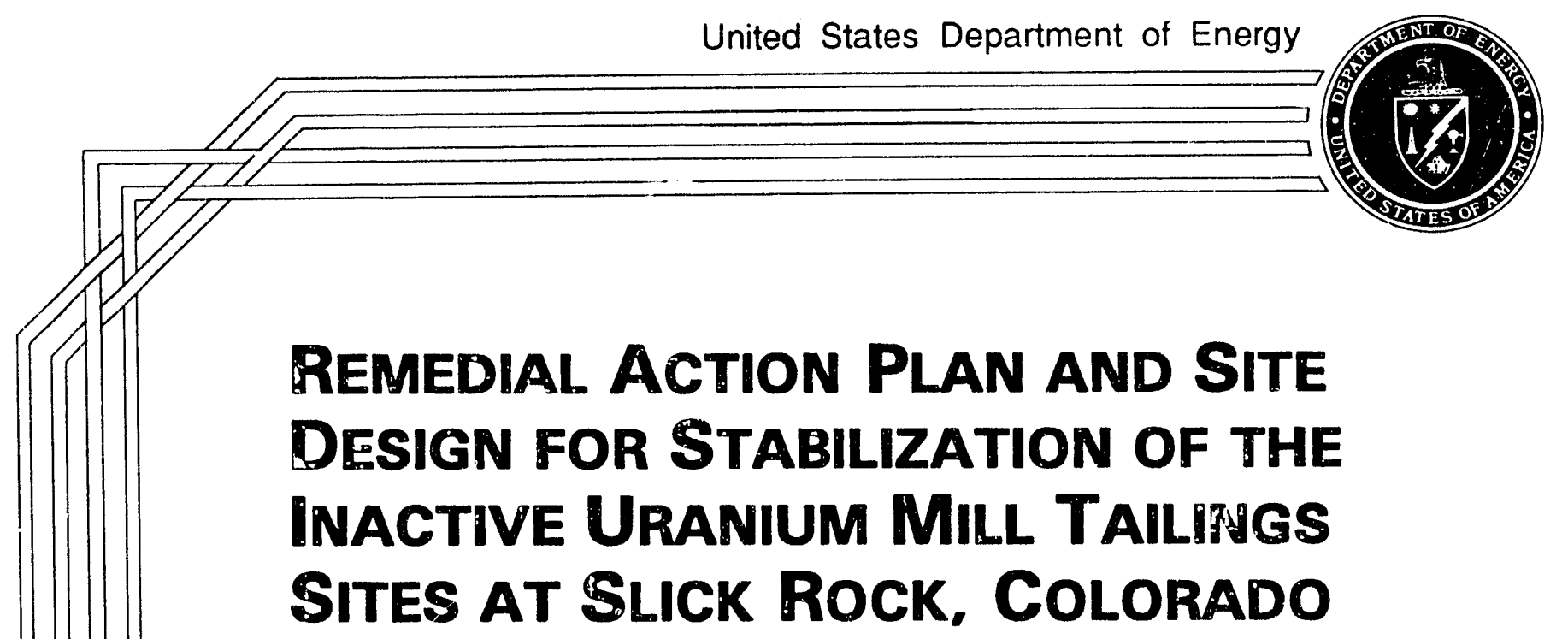

Attachment 3, Groundwater Hydrology Report

Draft

July 1993

Appendix $B$ of the

Cooperative Agreement

No. DE-FC04-81AL16257

Uranium Mill Tailings Remedial Action Project 
INTENDED FOR PUBLIC RELEASE

This report has been reproduced from the best available copy. Available in paper copy and microfiche.

Number of pages in this report: 64

DOE and DOE contractors can obtain copies of this report from:

Office of Scientific and Technical Information

P.O. Box 62

Oak Ridge, TN 37831

(615) 576-8401

This report is publicly available from:

National Technical Information Service

Department of Commerce

5285 Port Royal Road

Springfield, VA 22161

(703) $487-4650$ 


\title{
REMEDIAL ACTION AND SITE DESIGN FOR STABILIZATION OF THE INACTIVE URANIUM MILL TAILINGS SITES AT SLICK ROCK, COLORADO
}

\section{ATTACHMENT 3 GROUNDWATER HYDROLOGY REPORT}

Draft

July 1993

\author{
Prepared for \\ U.S. Department of Energy \\ UMTRA Project Office \\ Albuquerque, New Mexico
}

\section{DISCLAIMER}

This report was prepared as an account of work sponsored by an agency of the United States Government. Neither the United States Government nor any agency thereof, nor any of their employees, makes any warranty, express or implied, or assumes any legal liability or responsibility for the accuracy, completeness, or usefulness of any information, apparatus, product, or process disclosed, or represents that its use would not infringe privately owned rights. Reference herein to any specific commercial product, process, or service by trade name, trademark, manufacturer, or otherwise does not necessarily constitute or imply its endorsement, recommendation, or favoring by the United States Government or any agency thereof. The views and opinions of authors expressed herein do not necessarily state or reflect those of the United States Government or any agency thereof.

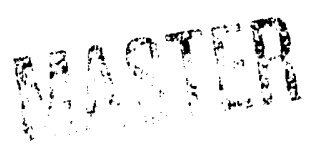


TABLE OF CONTENTS

Section Page

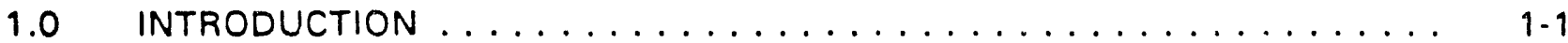

2.0 HYDROGEOLOGICAL SITE CHARACTERIZATION SUMMARY . . . . . . $2-1$

2.1 Slick Rock North Continent and Union Carbide processing sites . . . . . 2.1

2.2 Burro Canyon disposal site ... . . . . . . . . . . . . . . . . 2-2

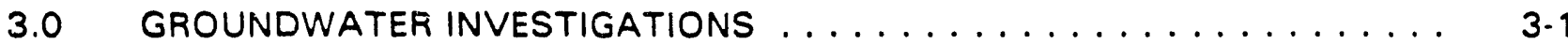

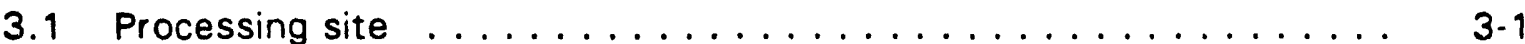

3.1.1 Previous investigations .............. $3-1$

3.1 .2 Geology and hydrostratigraphy ............. $3-2$

3.1.3 Occurrence of groundwater .............. 3.5

3.1.4 Hydraulic characteristics ................ 3.9

3.1.5 Background groundwater quality ............ 3.11

3.1.6 Tailings and milling process characterization ........ 3.16

3.1.7 Extent of groundwater contamination . . . . . . . . 3.19

3.1.8 Geochemical conditions .................. 3.31

3.1.9 Groundwater use, value, and alternative supplies . . . . . . 3.33

3.2 Disposal site .......................... 3.33

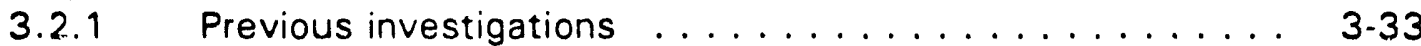

3.2.2 Geology and hydrostratigraphy .............. 3.36

3.2.3 Presence and movement of groundwater .......... 3-38

3.2.4 Hydiaulic characteristics ............... 3.45

3.2.5 Background groundwater quality ............. 3.47

3.2.6 Groundwater use, value, and alternative supplies ..... . 3-50

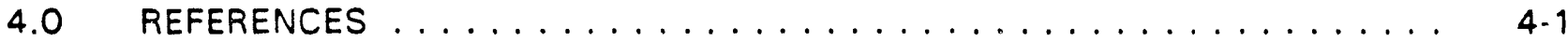

APPENDIX A TABLES

APPENDIX B DOE LITHOLOGIC LOGS

APPENDIX C CALCULATIONS 
LIST OF FIGURES

Figure

Page

3.1 Monitor well location map of the UC and NC processing sites, Slick Rock, Colorado . . . . . . . . . . . . . . . . . . . . . . .

3.2 Stratigraphic cross section at the UC and NC processing sites,

3.3 Water table contour map for the Dolores River alluvial wells at the UC and NC processing sites, Slick Rock, Colorado . . . . . . . . . . . . . . .

3.4 Potentiometric surface map for the Entrada Formation wells at the UC processing site, Slick Rock, Colorado . . . . . . . . . . . . . . . . . .

3.5 Potentiometric surface map for the Navajo Sandstone wells at the UC and NC processing sites, Slick Rock, Colorado . . . . . . . . . . . . .

3.6 Distribution of sulfate in the alluvial aquifer in the vicinity of the UC and NC processing sites, Slick Rock, Colorado . . . . . . . . . . . . .

3.7 Distribution of molybdenum in the alluvial aquifer in the vicinity of the UC and NC processing sites, Slick Rock, Colorado . . . . . . . . . . . . .

3.8 Distribution of nitrate in the alluvial aquifer in the vicinity of the UC and NC processing sites, Slick Rock, Colorado . . . . . . . . . . . . . . .

3.9 Distribution of uranium in the alluvial aquifer in the vicinity of the UC and NC processing sites, Slick Rock, Colorado . . . . . . . . . . . . . .

3.10 Nionitor well location map and north-south (A-A') cross section at the Burro Canyon disposal site, Colorado . . . . . . . . . . . . . . . . . .

3.11 Stratigraphy along the north-south $\left(A-A^{\prime}\right)$ cross section at the Burro Canyon disposal site, Colorado . . . . . . . . . . . . . . . . . .

3.12 Potentiometric surface contour map of the Burro Canyon upper sandstone unit at the Burro Canyon disposal site, Colorado . . . . . . . . . . .

3.13 Groundwater hydrograph of the Burro Canyon upper sandstone unit at the Burro Canyon disposal site, Colorado . . . . . . . . . . . . . . . .

3.14 Potentiometric surface contour map of the Burro Canyon middle sandstone unit at the Burro Canyon disposal site, Colorado . . . . . . . . . . . . .

3.15 Groundwater hydrograph of the Burro Canyon middle sandstone unit at the Burro Canyon disposal site, Colorado . . . . . . . . . . . . . . . . . .

3.16 Potentiometric surface contour map of the Burro Canyon lower sandstone unit at the Burro Canyon disposal site, Colorado . . . . . . . . . . .

3.17 Groundwater hydrograph of the Burro Canyon lower sandstone unit at the Burro Canyon disposal site, Colorado . . . . . . . . . . . . . . . . . . . 


\section{LIST OF ACRONYMS AND ABBREVIATIONS}

\section{Acronym Definition}

\begin{tabular}{|c|c|}
\hline $\begin{array}{l}\text { ac } \\
\text { bls }\end{array}$ & $\begin{array}{l}\text { acre } \\
\text { below land surface }\end{array}$ \\
\hline $\begin{array}{l}\mathrm{b} / \mathrm{s} \\
\mathrm{cm} / \mathrm{s}\end{array}$ & $\begin{array}{l}\text { below land surface } \\
\text { centimeter per second }\end{array}$ \\
\hline $\begin{array}{l}\mathrm{Cm} / \mathrm{s} \\
\mathrm{DOE}\end{array}$ & $\begin{array}{l}\text { centimeter per second } \\
\text { U.S. Department of Energy }\end{array}$ \\
\hline EPA & U.S. Environmental Protection Agency \\
\hline $\begin{array}{l}\mathrm{ft} \\
\mathrm{ft} / \mathrm{day} \\
\mathrm{ft} / \mathrm{yr}\end{array}$ & $\begin{array}{l}\text { feet } \\
\text { feet per day } \\
\text { feet per year }\end{array}$ \\
\hline g & gram \\
\hline gpd & gallons per day \\
\hline gpm & gallons per minute \\
\hline ha & hectare \\
\hline hr & hour \\
\hline in & inch \\
\hline$K_{d}$ & distribution coefficient \\
\hline $\mathrm{kg} / \mathrm{d}$ & kilograms per day \\
\hline km & kilometer \\
\hline$L / S$ & liters per second \\
\hline$m$ & meter \\
\hline$m^{2}$ & square meter \\
\hline MCL & maximum concentration limit \\
\hline meq & milliequivalent \\
\hline $\mathrm{mg} / \mathrm{l}$ & milligrams per liter \\
\hline $\mathrm{mi}$ & mile \\
\hline $\mathrm{msl}$ & mean sea level \\
\hline$m V$ & millivolt \\
\hline NC & North Continent \\
\hline NEPA & National Environmental Policy Act \\
\hline $\mathrm{pCi} / \mathrm{L}$ & picocuries per liter \\
\hline $\mathrm{Ra}$ & radium \\
\hline RAP & remedial action plan \\
\hline $\begin{array}{l}\text { SPEAR } \\
\text { TAD }\end{array}$ & $\begin{array}{l}\text { Software Program for Environmantal Analysis and Reporting } \\
\text { Technical Approach Document }\end{array}$ \\
\hline TDS & total dissolved solids \\
\hline UC & Union Carbide \\
\hline UMTRA & Uranium Mill Tailings Remedial Action \\
\hline UMTRCA & Uranium Mill Tailings Radiation Control Act \\
\hline VP & vicinity properties \\
\hline yr & year \\
\hline
\end{tabular}




\subsection{INTRODUCTION}

The U.S. Environmental Protection Agency (EPA) has established health and environmental protection regulations to correct and prevent groundwater contamination resulting from processing activities at inactive uranium milling sites (EPA, 1987). According to the Uranium Mill Tailings Radiation Control Act (UMTRCA) of 1978 Public Law (PL) 95-604 (PL 95-604), the U.S. Department of Energy (DOE) is responsible for assessing the inactive uranium processing sites. The DOE has determined that for Slick Rock, this assessment shall include hydrogeologic site characterization for two separate uranium processing sites, the Union Carbide (UC) site and the North Continent (NC) site, and for the proposed Burro Canyon disposal site. The water resources protection strategy that describes how the proposed action will comply with the EPA groundwater protection standards is presented in Attachment 4. The following site characterization activities are discussed in this attachment:

- Characterization of the hydrogeologic environment, including hydrostratigraphy, groundwater occurrence, aquifer parameters, and areas of recharge and discharge.

- Characterization of existing groundwater quality by comparison with background water quality and the maximum concentration limits (MCL) of the proposed EPA groundwater protection standards.

- Definition of physical and chemical characteristics of the potential contaminant source, including concentration and leachability of the source in relation to migration in groundwater and hydraulically connected surface water.

- Description of local water resources, including current and future use, availability, and alternative supplies.

The EPA promulgated final groundwater protection standards for the disposal and cleanup of the inactive uranium processing sites under the UMTRCA on January $5,1983$. However, the groundwater provisions of the regulations [40 CFR 192.20(a)(2)-(3)] were remanded back to the EPA by the U.S. Tenth Circuit Court of Appeals on September 3, 1985. The EPA issued proposed groundwater standards (EPA, 1987) on September 24, 1987. Table 1.1 of Appendix A summarizes these groundwater standards.

Under the UMTRCA, the DOE must comply with the proposed groundwater protection standards until the final standards are promulgated. Consequently, remedial action at the Slick Rock processing sites and the proposed Burro Canyon disposal site will not affect the selection or implementation of reasonable groundwater restoration methods that may be necessary when the final standards are promulgated. When the final EPA standards are promulgated, the DOE will again evaluate the groundwater protection and cleanup requirements and determine the need for institutional or other controls to ensure compliance with the regulations. Evaluation of aquifer restoration and control of existing groundwater contamination at the Slick Rock UC and NC processing sites will be addressed under a separate phase in accordance with the National Environmental Policy Act (NEPA). 


\subsection{HYDROGEOLOGICAL SITE CHARACTERIZATION SUMMARY}

The DOE has characterized the hydrogeology, water quality, and water resources at the Slick Rock UC and NC processing sites and the Burro Canyon disposal site. Major points are surnmarized below.

\subsection{SLICK ROCK NORTH CONTINENT AND UNION CARBIDE PROCESSING SITES}

- The sites are located approximately 1 mile (mi) $[1$ kilometer $(\mathrm{km})]$ from each other, along the banks of the Dolores River. Groundwater conditions in the Slick Rock area are highly dependent on local topographic and stratigraphic structural features. Canyon cutting, tectonic fracturing, and discontinuities between the geologic formations have caused distinct stratigraphic units to become hydraulically connected. Additional information is provided in Section 3.1.2.

- The uppermost aquifer at the UC and NC sites consists of Dolores River alluvium, underlain by Entrada Sandstone (Slick Rock and Dewey Bridge Members) and Navajo Sandstone. These three hydrostratigraphic units are unconfined to semiconfined, have variable permeabilities, and are believed to be hydraulically connected.

- Groundwater flow is unconfined in the Dolores River alluvium and is expected to be semiconfined in the underlying Entrada and Navajo Sandstone Formations. Groundwater elevations in the alluvium, Entrada Sandstone, and the Navajo Sandstone remain relatively constant, regardless of the time of year. Details regarding groundwater occurrence and the hydraulic characteristics of these formations are provided respectively in Sections 3.1.3 and 3.1.4.

- Background groundwater quality is defined as the quality of groundwater that would be expected at the site if uranium processing had not occurred. Concentrations or activities of chromium, molybdenum, uranium, and radium (Ra) -226 and -228 have exceeded the MCLs listed in 40 CFR 192 of the EPA-proposed groundwater standards in one or more background alluvial monitor wells.

- The chemical characteristics of the NC and UC tailings materials were evaluated by pore fluid sampling with suction lysimeters. The $\mathrm{pH}$ of the tailings pore fluid is near neutral, ranging from 6.2 to 7.8. Total dissolved solids (TDS) range from approximately 2400 to 33,900 milligrams per liter $(\mathrm{mg} / \mathrm{L})$. Average concentrations of arsenic, cadmium, molybdenum, selenium, and uranium exceeded the MCLs in lysimeter samples collected from the NC site. At the UC site, the average pore fluid concentrations of cadmium, molybdenum, nitrate, selenium, and uranium exceeded MCLs. 
- On-site and downgradient (baseline) water quality has been compared to that of vackground groundwater. Average TDS concentrations in baseline alluvial groundwater are approximately three times those of background. The hazardous constituents of concern in the Dolores River alluvium are molybdenum, nitrate, selenium, and uranium at the UC processing site and selenium and uranium at the NC processing site. The baseline water quality of the Entrada Formation also appears to be affected by uranium processing activities because 1) the average concentrations of TDS in baseline Entrada Formation monitor wells are approximately three times those observed in background Entrada Formation monitor wells and 2) concentrations of selenium exceed the MCL and background. Baseline water quality in the Navajo Sandstone does not appear to be affected by processing activities. TDS, $\mathrm{pH}$, and the regulated constituents show minimal variation between background and baseline water quality.

- Eleven domestic wells are registered in the vicinity of the Slick Rock tailings sites; however, none of these wells are expected to be affected by the tailings materials at the Slick Rock processing sites, for the reasons discussed in Section 3.1.9.

- One unsaturated unit and three saturated units are present below the Burro Canyon disposal site. The unsaturated unit immediately underlying the site consists of the Dakota Sandstone and the Burro Canyon mudstone. The three saturated sandstone units begin at approximate depths of 100,200 , and 300 feet $(\mathrm{ft})[30,60$, and 90 meters $(\mathrm{m})]$. These units are described as the upper, middle, and lower units, respectively. Each unit is composed of fine- to medium-grained sandstone layers and is 25 to $75 \mathrm{ft}(7.6$ to $23 \mathrm{~m})$ thick. The units are hydrogeologically separated from each other by unsaturated interbedded mudstone and siltstone sequences. Additional information is provided in Section 3.2.2.

- The upper sandstone unit of the Burro Canyon Formation is the first saturated unit and is the uppermost aquifer at the Burro Canyon disposal site. The upper sandstone unit has Class III groundwater, as defined in 40 CFR 192.11(e) of the EPA-proposed groundwater standards, meaning that groundwater is not a current or potential source of drinking water because the quantity of water available is less than 150 gallons per day (gpd) $\left[7 \times 10^{-3}\right.$ liters per second (L/S)]. Pumping tests were conducted in wells screened in the upper sandstone unit. However, the wells could not sustain the 150-gpd $\left(7 \times 10^{.3} \mathrm{~L} / \mathrm{s}\right)$ rate for an extended period of time. The middle sandstone unit of the Burro Canyon Formation is a confined aquifer that is separated from the upper sandstone unit by approximately 60 to $70 \mathrm{ft}(17$ to $23 \mathrm{~m})$ of mudstone. The middle sandstone unit has a substantial upward vertical hydraulic gradient. Groundwater in the lower sandstone unit is also confined by a thick sequence 140 to $60 \mathrm{ft} 112$ to $18 \mathrm{~m})$ ] of low-permeability mudstones that separate the middle and lower 
sandstone units of the Burro Canyon Formation. The lower sandstone unit has a low yield and low velocity. Additional discussion of groundwater occurrence and hydraulic properties of the Burro Canyon Formation are presented in Sections 3.2.3 and 3.2.4.

- Vertical recharge to and discharge from the Burro Canyon sandstone units are restricted because the low-permeability interbedded claystone and siltstone strata impede infiltration into the water-bearing units. The source of recharge to the uppermost aquifer is northeast of the site, where the sandstone beds outcrop along the east limb of the Disappointment syncline, intercepting tributaries to the Nicholas Wash drainage system. Groundwater then flows to the south-southeast and eventually dissipates (discharges) into the surrounding geologic strata south of the Burro Canyon disposal site.

- Background groundwater quality in each hydrostratigraphic unit within the Burro Canyon Formation was determined from monitoring groundwater in wells completed in each unit. In general, groundwater $\mathrm{pH}$ is fairly neutral, and TDS concentrations tend to decrease with depth; TDS concentrations range from 556 to $973 \mathrm{mg} / \mathrm{L}$ in the upper sano'stone, 422 to $696 \mathrm{mg} / \mathrm{L}$ in the middle sandstone, and 256 to $485 \mathrm{mg} / \mathrm{L}$ in the lower sandstone. The only naturally occurring hazardous constituents exceeding the proposed EPA MCLs are selenium and Ra-226 and -228 in the upper sandstone unit and Ra-226 and -228 in the middle sandstone unit. These exceedances have occurred in one or more wells in 1991 and 1992.

- Mudstones and claystones of the Burro Canyon Formation are very impermeable to the transmission of groundwater and will provide an effective barrier to leachate seeping through the radon barrier. However, if leachate seeps into the Burro Canyon Formation, the upward hydraulic gradients in the middle and lower sandstone units will prohibit further contaminant migration for up to 1000 years $(y r)$ to the extent reasonably achievable and, in any case, for at least $200 \mathrm{yr}$ as required in 40 CFR 192.

- No known registered wells or private wells in the upper sandstone unit of the Burro Canyon Formation are actively used within a $2-\mathrm{mi}(3-\mathrm{km})$ radius of the Burro Canyon disposal site. 


\subsection{GROUNDWATER INVESTIGATIONS}

\subsection{PROCESSING SITE}

\subsubsection{Previous investigations}

Site-specific studies that addressed groundwater at the Slick Rock NC and UC processing sites were initiated in 1981 when an engineering assessment was conducted by Ford, Bacon \& Davis Utah Inc. (FBIJU, 1981). In November 1984, the DOE initiated a reconnaissance investigation of the Slick Rock NC and UC sites. Initial hydrogeologic characterization efforts at the processing sites continued through 1986. These investigations included the installation of six shallow monitor wells in the Dolores River alluvium, four deep monitor wells in the Navajo Sandstone, nine auger borings to the top of bedrock, and three test pits. From this limited hydrogeological characterization it appeared that 1) the Navajo Sandstone was confined by the Entrada Formation, and 2) an upward potentiometric gradient existed from the Navajo Sandstone in the Entrada Formation.

Additional site characterization at the UC site continued during 1987. Related field activities included excavating 21 test pits, conducting surface geophysics, drilling 10 borings, and packer testing 2 boreholes in the Entrada Formation. In November 1988, the DOE reviewed site data gathered to assess the final design for groundwater compliance and to prepare the final remedial action plan (RAP). Borings were drilled, test pits were excavated, and monitoring wells and lysimeters were installed. Sediment, tailings, surface water, groundwater, and lysimeter pore fluid samples were collected at the NC and UC processing sites and analyzed to characterize existing conditions. Lysimeter pore fluid samples were analyzed to characterize the tailings source term. Data produced from some of these field activities suggested that the Entrada Formation was not laterally extensive across the site and did not completely separate the Dolores River alluvium from the Navajo Sandstone, as was previously thought.

The DOE drilled one borehole and installed three monitor wells in the Entrada Formation in 1989. Unconfined, near-surface groundwater was encountered in these monitor wells. Additional drilling in the Entrada Formation indicated the presence of buried paleochannels incised by the ancestral Dolores River. In August 1989, the DOE completed a seismic refraction survey across the UC processing site. Paleochannels and river terraces buried by more recent deposits were verified as a result of the seismic refraction survey.

To more accurately define these subsurface features, the DOE initiated a final site characterization drilling program. Ten monitor wells and twelve exploratory boreholes were installed in September 1989. This program identified 1) the locations, dimensions, and gradients of paleochannels; 2 ) numerous terraces associated with the incision of the Dolores River; 3 ) the presence of unconfined, near-surface groundwater in the Entrada Formation and the Navajo Sandstone 
across parts of the UC processing site; and 4) the susceptibility of the Navajo Sandstone aquifer to contamination, caused by localized erosion of the Entrada Formation confining beds. As a result, it was concluded that the Entrada Formation was not a laterally extensive confining unit as was originally thought. Additional information regarding groundwater occurrence and hydraulic properties is provided in Sections 3.1 .3 and 3.1.4, respectively.

The locations of monitor wells at the UC and NC processing sites are shown on Figure 3.1. Monitor well construction information is provided in Tables 3.1 and 3.2 of Appendix A, for the NC and UC processing sites, respectively. Lithologic logs and construction information for all DOE monitor wells are provided in Appendix B. In the following discussions, all reported depths are measured from ground surface.

Groundwater elevations have been measured and water table maps have been constructed to determine the direction of groundwater flow and hydraulic gradients. Slug tests were performed in the shallow alluvial material and in the Navajo Sandstone to estimate hydraulic conductivity and transmissivity. Groundwater samples have been collected from monitor wells and analyzed to determine groundwater quality and to establish the nature and extent of contamination caused by uranium processing activities. The frequency and duration of sample collection are functions of when the monitor wells were installed, their proximity to the processing sites, and water quality data.

\subsubsection{Geology and hydrostratigraphy}

The UC and NC sites are located approximately $1 \mathrm{mi}(1.6 \mathrm{~km})$ from each other, along the banks of the meandering Dolores River, as shown in Figure 3.1. Both sites are within the deeply entrenched Dolores River valley at elevations of approximately $5500 \mathrm{ft}(1700 \mathrm{~m})$ above mean sea level (msl). The sites are located on gently sloping terrace surfaces dissected by small stream channels and gullies. Bedrock ridges and cliffs on either side of the river rise to elevations of 5600 to $6200 \mathrm{ft}(1700$ to $1900 \mathrm{~m})$ above $\mathrm{msl}$. The existing tailings piles are within the modern floodplain of the Dolores River. In their present locations, both piles are subject to potential tailings dispersal caused by flooding.

Contaminants continue to leach into the unuerlying Dolores River alluvial grcundwater.

The uppermost aquifer consists of Dolores River alluvium underlain by Entrada Formation (Slick Rock and Dewey Bridge Members) and Navajo Sandstone. A hydrostratigraphic cross section transecting both the UC and NC processing sites is provided in Figure 3.2. These three hydrostratigraphic units are unconfined to semiconfined, have variable permeabilities, and are believed to be hydraulically connected, as discussed in Sections 3.1.3 and 3.1.4.

The Dolores River alluvium is composed of widespread unconsolidated clayey sands, sandy gravels, and cobbles from the ground surface to an approximate depth of $20 \mathrm{ft}(6 \mathrm{~m})$ at both the UC and NC sites. The modern Dolores River 


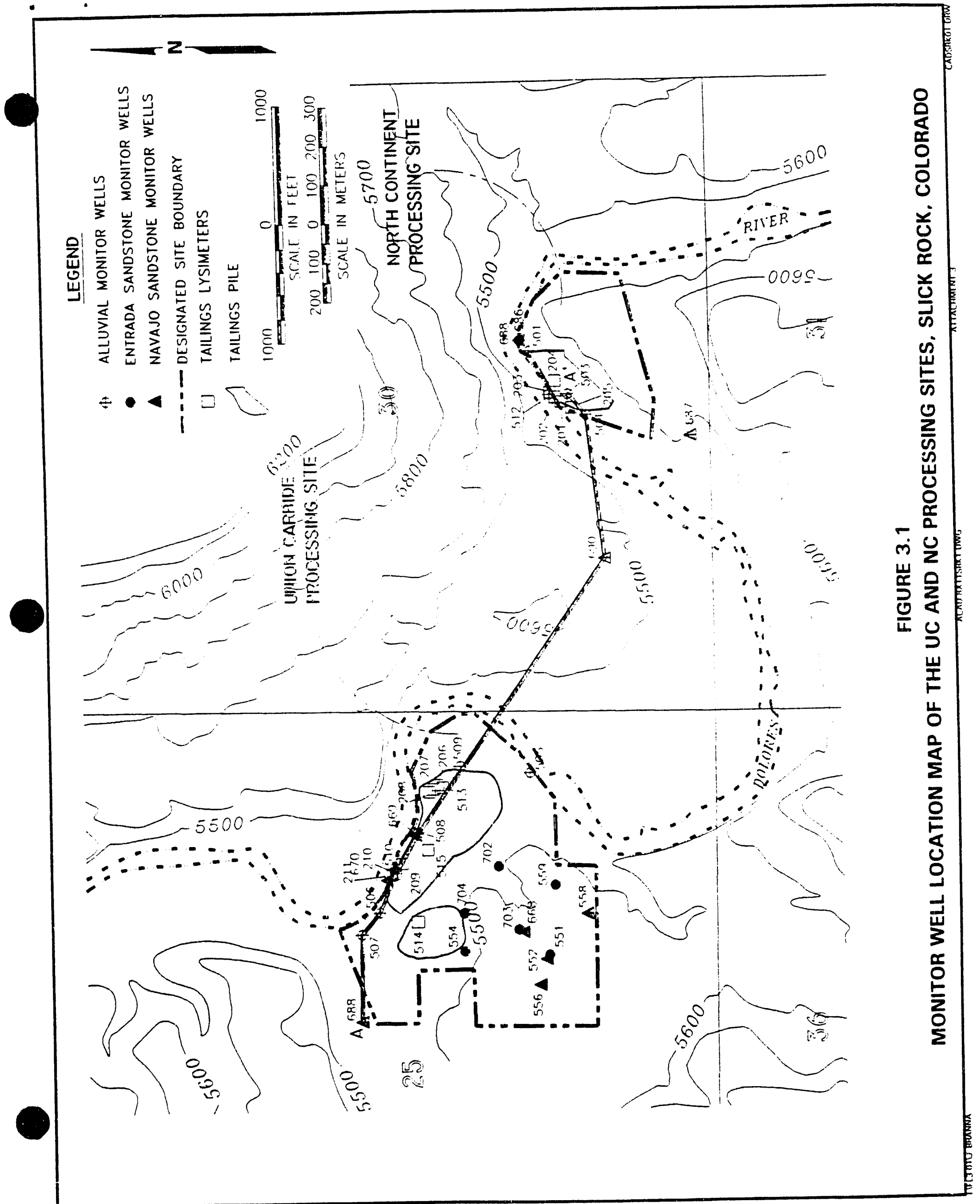



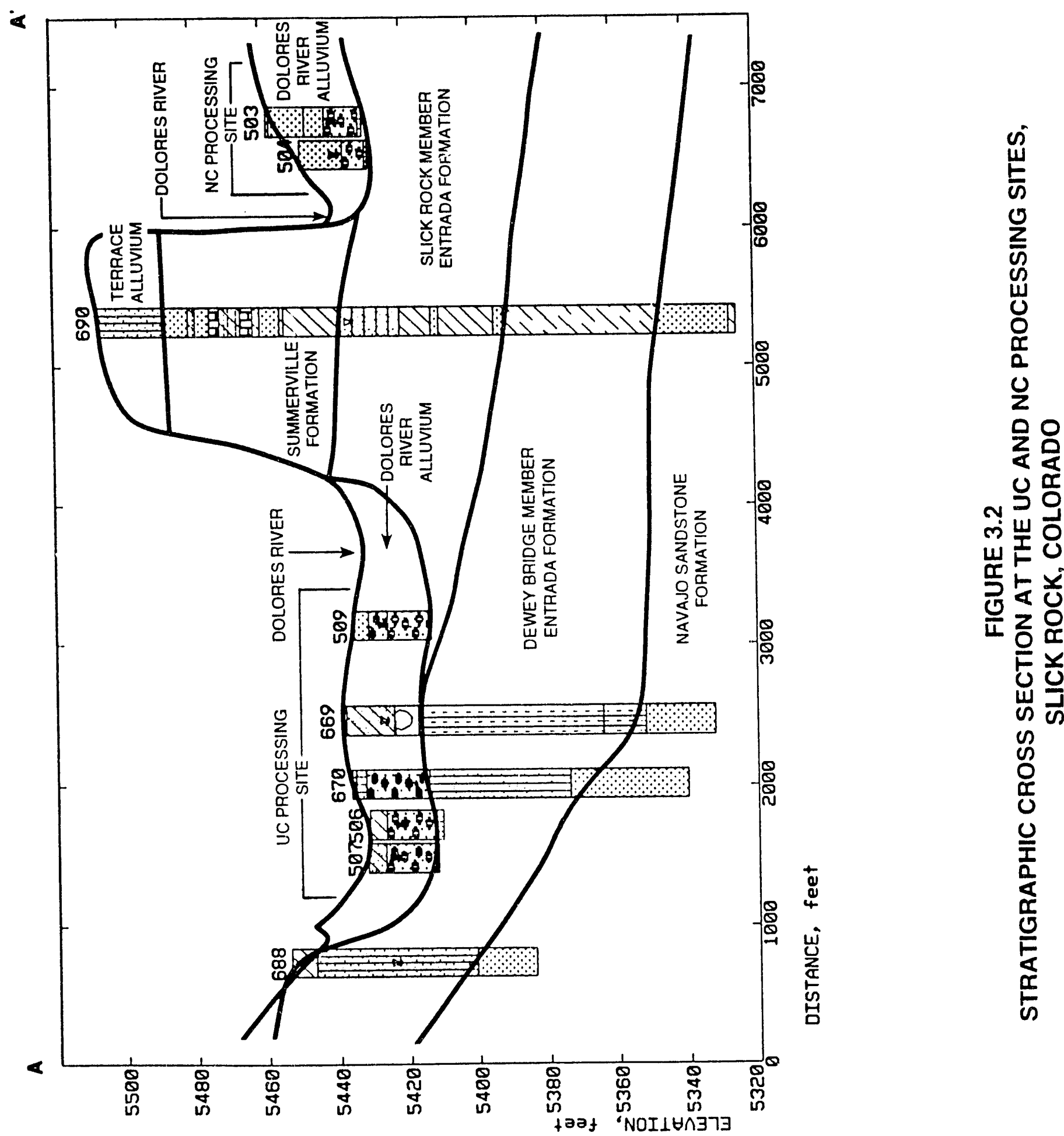
channel has diverted the alluvium into discrete lenticular bodies that vary between 250 to $600 \mathrm{ft}(80$ to $180 \mathrm{~m})$ in width and 1000 to $4000 \mathrm{ft}(300$ to $1200 \mathrm{~m}$ ) in length. Quaternary alluvium materials also cap the tops of terraces surrounding the Dolores River floodplain.

The Jurassic Summerville Formation underlies Quaternary alluvial terraces and forms the canyon walls of the terraces surrounding the Dolores River floodplain, as shown in Figure 3.2. The Dolores River meanders around these terraces. The Summerville consists of erosive layers of interbedded reddish-brown mudstones and siltstones, and some fine-grained sandstone, limestone, and shale that erode readily.

Jurassic Entrada Formation underlies the alluvium in the Dolores River floodplain and underlies the Summerville Formation in terraced areas adjacent to the floodplain. The canyon walls of these terraces consist of sandstones, mudstones, and shales of the Summerville Formation. Two members of the Entrada Formation are present: the Slick Rock Member and the Dewey Bridge Member. The Slick Rock Member underlies the Summerville Formation and alluvial deposits at the NC processing site and pinches out under the UC processing site. The Slick Rock Member is composed of light brown, fine-grained sand that is generally not well cemented and is therefore easily eroded.

The Dewey Bridge Member of the Entrada Formation underlies the Slick Rock Member at the NC processing site. At the UC site, where the Slick Rock Member is absent, the Dewey Bridge Member directly underlies Dolores River alluvium. The Dewey Bridge Member ranges from 20 to $38 \mathrm{ft}(6$ to $12 \mathrm{~m}$ ) thick in the Slick Rock area (Shawe et al., 1968). The Dewey Bridge Member is more impermeable than the Slick Rock Member, consisting of reddish-brown, clayey siltstone, very fine-grained sandstone, and shale. The Dewey Bridge and Slick Rock Members of the Entrada Formation were encountered beneath the alluvial deposits to depths ranging from 20 to $160 \mathrm{ft}$ (6 to $49 \mathrm{~m}$ ).

The Navajo Sandstone underlies the Entrada Formation throughout the Slick Rock area at depths ranging from 53 to $170 \mathrm{ft}(16$ to $52 \mathrm{~m})$ below land surface (bls). The formation is composed of light-brown to reddish-brown, fine-grained sandstone. The bottom of the Navajo Sandstone was not encountered in any of the DOE borings; therefore, the thickness of the Navajo Sandstone has not been determined directly in the area of the Slick Rock processing sites. However, Shawe et al. (1968) report the Navajo Formation ranges from 0 to $420 \mathrm{ft}$ $(128 \mathrm{~m})$ thick in the Slick Rock district.

\subsubsection{Qccurrence of groundwater}

Groundwater conditions at the Slick Rock processing sites depend highly on local structural, stratigraphic, and topographic features. Canyon cutting, tectonic fracturing, and discontinuities between the geologic formations are believed to have caused distinct stratigraphic units to become hydraulically connected. 
The uppermost aquifer at the NC and UC sites consists of three hydrostratigraphic units: 1) Quaternary alluvium associated with the Dolores River floodplain deposits, 2) the Slick Rock and Dewey Bridge Members of the Entrada Formation, and 3) the Navajo Sandstone. Groundwater flow is unconfined in the alluvium and is expected to be semiconfined in the underlying Entrada Formation and unconfined to semiconfined in the Navajo Sandstone Formation. These three formations appear to be hydraulically connected, based on lithologic data and groundwater levels. Static groundwater levels at the Slick Rock processing sites are provided in Table 3.3 of Appendix A. Groundwater elevations in the alluvium, the Entrada Formation, and the Navajo Sandstone remain relatively constant and do not show seasonal fluctuations.

\section{Groundwater conditions in the Dolores River alluvium}

The occurrence of groundwater in the alluvium at the processing sites is limited to the recent channels and paleochannels of the Dolores River. Water table elevations measured in the Dolore's River alluvium underlying the Slick Rock processing sites are shown on Figure 3.3 for December 1992. The depth to groundwater at both processing sites ranges from 10 to $20 \mathrm{ft}(3$ to $6 \mathrm{~m})$ in wells screened in the alluvium. The unconfined groundwater level in the alluvium under the tailings piles is approximately the same as the surface water levels of the Dolores River. The water table contour map indicates that groundwater in the alluvium flows toward the Dolores River. Groundwater flows generally to the north in the alluvium. The hydraulic gradient ranges from 0.003 at the NC site to 0.008 at the UC site. The alluvial aquifer is recharged by seepage from the Dolores River upstream of the NC site and by precipitation. Groundwater discharges from the alluvium into the Dolores River downgradient of the UC site.

\section{Groundwater conditions in the Entrada Formation}

In monitor wells screened in the Entrada Formation, the depth to groundwater is approximately 27 to $45 \mathrm{ft}(8$ to $14 \mathrm{~m})$. Groundwater elevations in the Entrada Formation are shown in Figure 3.4, for December 1992. No monitor wells are screened in the Entrada Formation at the NC site; therefore, the information available for groundwater movement in the Entrada Formation is limited. However, the potentiometric surface map for the UC site presented in Figure 3.4 suggests that groundwater movement is generally to the east in the Entrada Formation. The static groundwater elevations are higher in the Entrada Formation than in the overlying alluvium, suggesting that an upward vertical gradient may exist locally. All Entrada wells are screened in the Dewey Bridge Member, which is believed to be more impermeable and more restrictive of groundwater movement than the other hydrostratigraphic units.

\section{Groundwater conditions in the Navaio Sandstone Formation}

In monitor wells screened in the Navajo Sandstone, the depths to groundwater vary from approximately 40 to $75 \mathrm{ft}(12$ to $23 \mathrm{~m})$ at the UC site and from 25 to 


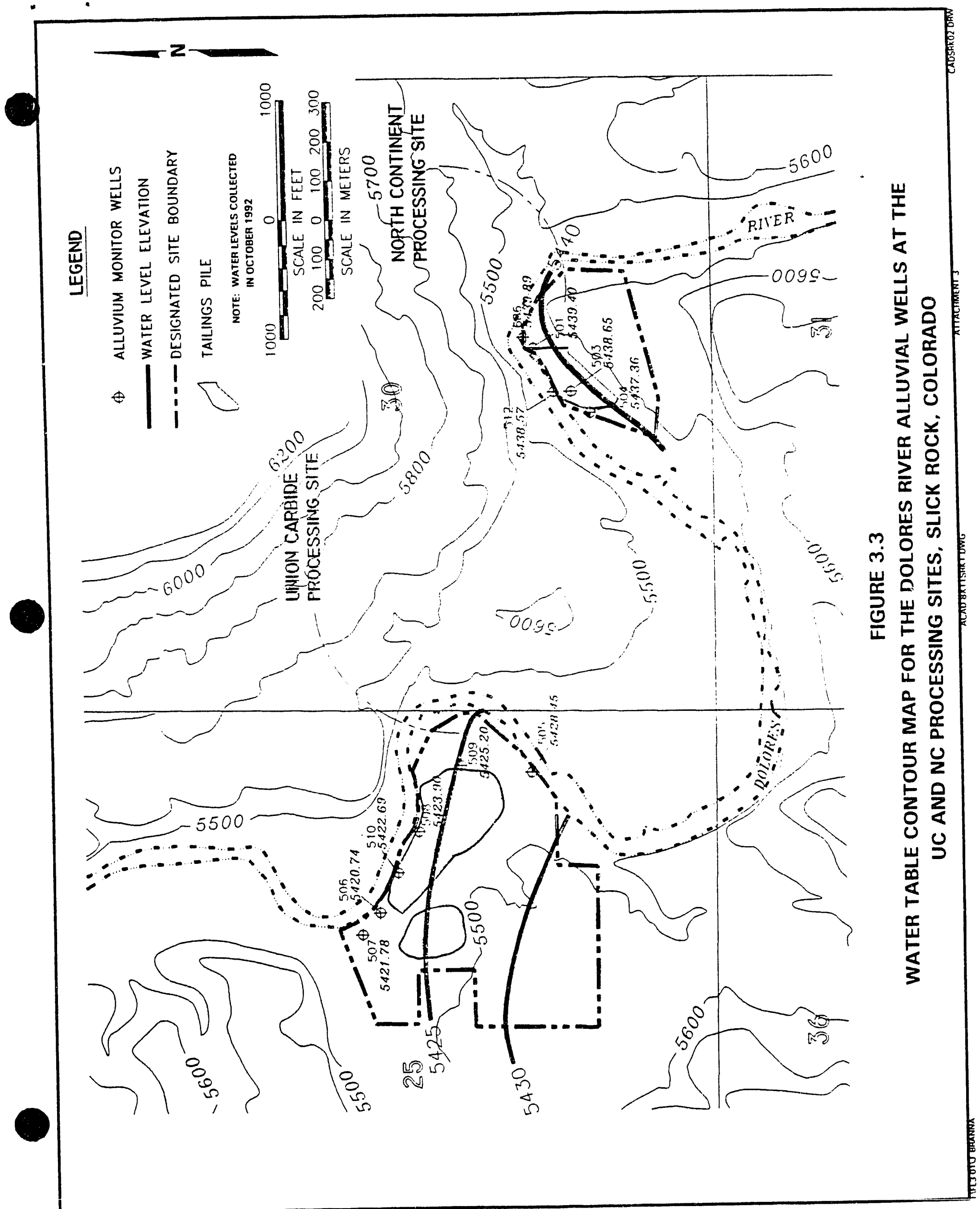




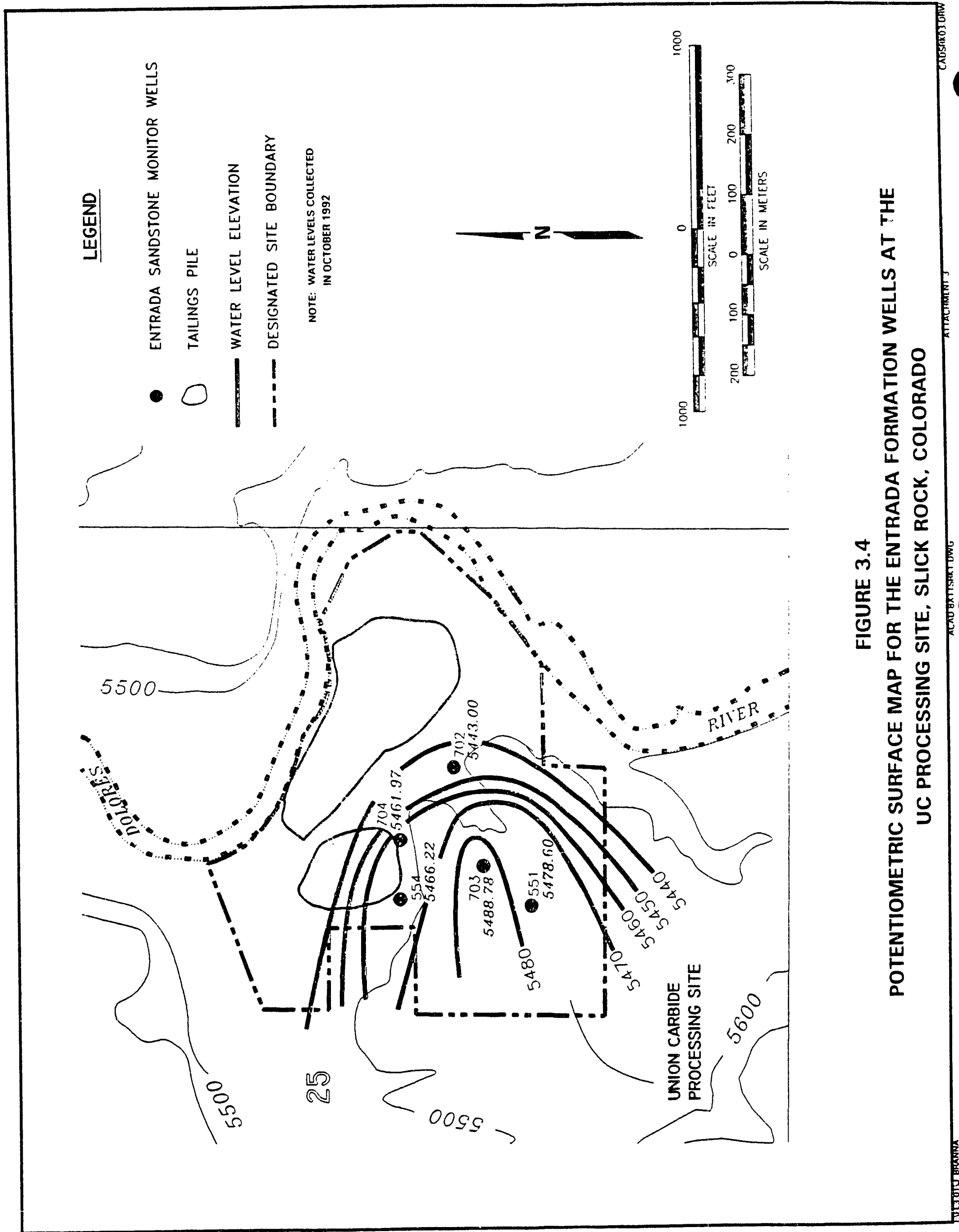


$60 \mathrm{ft}(8$ to $18 \mathrm{~m})$ at the NC site. Groundwater elevations in the Navajo Sandstone Formation are shown in Figure 3.5, for December 1992. The direction of groundwater flow is generally to the north at both processing sites. The variability in the directions of the groundwater contours is expected to be a result of preferential flowpaths caused by differences in subsurface material permeability, in and adjacent to the ancient buried channel of the Dolores River. Static groundwater elevations are lower in the Navajo Sandstone than in the overlying Entrada Formation and some static groundwater elevations are roughly the same as those of wells screened in the Dolores River alluvium. These static water levels suggest that groundwater in the Navajo Sandstone is unconfined to semiconfined, depending upon the permeability and thickness of the overlying hydrostratigraphic units.

Site characterization activities conducted in September 1989 indicated the presence of paleochannels at the UC site. Lithologic data suggest that paleochannels have eroded through the Entrada Formation into the Navajo Sandstone and contribute up to $50 \mathrm{ft}(15 \mathrm{~m})$ of highly permeable gravel. Because the Entrada Formation has been partially eroded away, the Navajo Sandstone is unconfined under portions of the UC site.

\subsubsection{Hydraulic characteristics}

Hydraulic characteristics were estimated in 1986 and 1987. Slug tests were conducted in the shallow alluvium and in the Navajo Sandstone at the NC and UC processing sites. The middle hydrostratigraphic unit, the Entrada Formation, was not tested.

\section{Dolores River alluvium}

Hydraulic conductivities estimated for the Dolores River alluvium and the Navajo Sandstone at the Slick Rock, Colorado, processing sites are shown in Table 3.4 of Appendix A. The hydraulic conductivity of the alluvium ranges from 5.8 to $51.3 \mathrm{ft} /$ day $\left[2.1 \times 10^{.3}\right.$ to $18.1 \times 10^{-3}$ centimeters per second $\left.(\mathrm{cm} / \mathrm{s})\right]$. At the NC site, the geometric mean hydraulic conductivity is $22.8 \mathrm{ft} /$ day $\left(8.0 \times 10^{.3}\right.$ $\mathrm{cm} / \mathrm{s})$. At the UC site, the geometric mean hydraulic conductivity is $13.3 \mathrm{ft} /$ day $\left(4.7 \times 10^{3} \mathrm{~cm} / \mathrm{s}\right)$.

Darcy's Law was used to calculate the average linear groundwater velocity in the alluvium at each tailings site, and the results are summarized in Table 3.5 of Appendix $A$. The average linear groundwater velocity in the alluvium at the NC site was estimated to be $100 \mathrm{ft} /$ day $\left(1.5 \times 10^{.4} \mathrm{~cm} / \mathrm{s}\right)$, based on an average hydraulic conductivity of $22.8 \mathrm{ft} /$ day $\left(8.0 \times 10^{-3} \mathrm{~cm} / \mathrm{s}\right)$, a hydraulic gradient of 0.003 , and an effective porosity of 0.25 for sand and gravel (Freeze and Cherry, 1979). The average linear groundwater velocity in the alluvium at the UC site was estimated to be $150 \mathrm{ft} / \mathrm{yr}\left(2.4 \times 10^{.4} \mathrm{~cm} / \mathrm{s}\right)$, based on an average hydraulic conductivity of $13.3 \mathrm{ft} /$ day $\left(4.7 \times 10^{.3} \mathrm{~cm} / \mathrm{s}\right)$, a hydraulic gradient of 0.008 , and an effective porosity of 0.25 . 


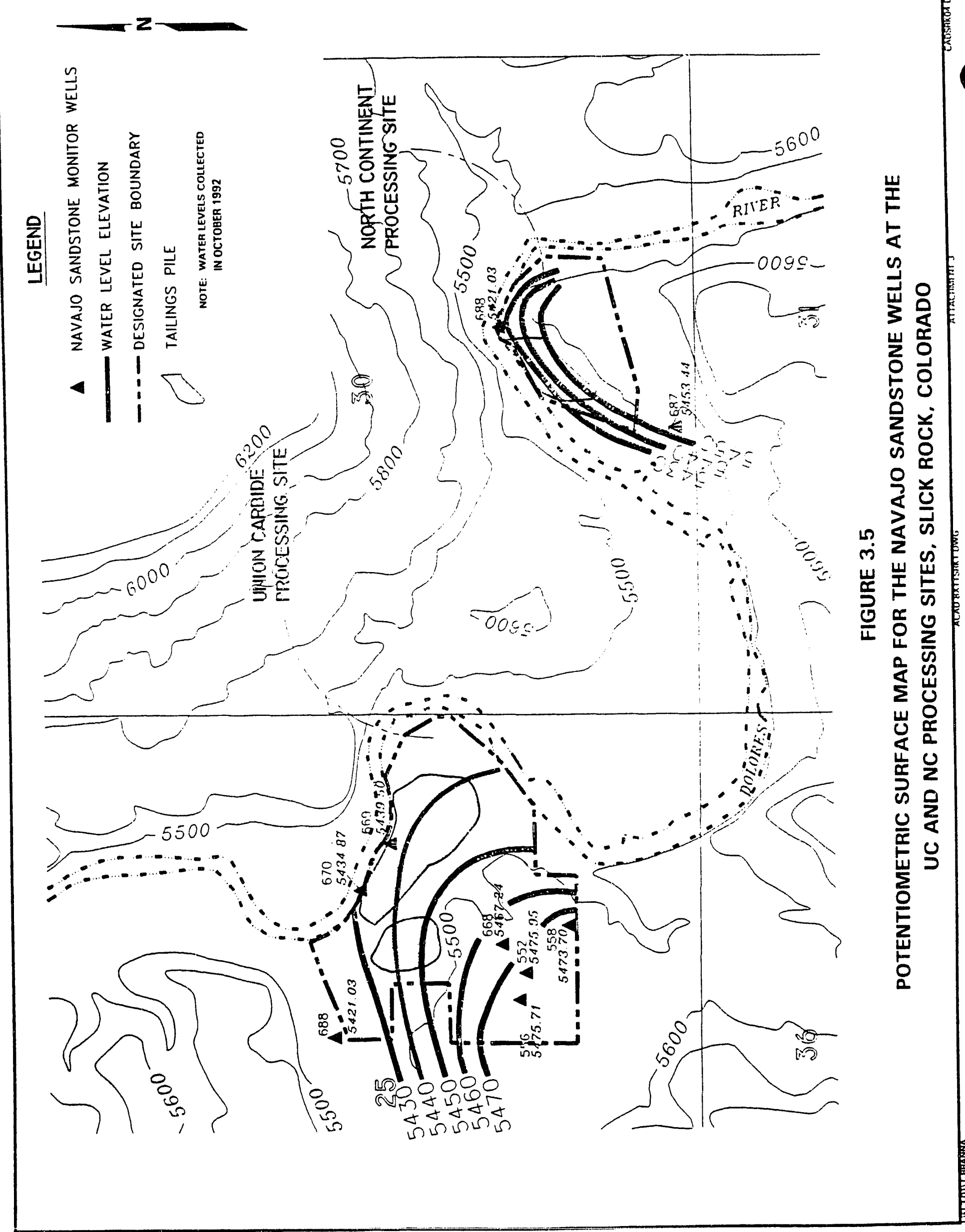


The hydraulic conductivity of the Navajo Sandstone is considerably less than that of the Dolores River alluvium. In the Navajo Sandstone, the hydraulic conductivity was estimated to range from $6.6 \times 10^{-3}$ to $1.9 \times 10^{-1} \mathrm{ft} /$ day $(2.3 \times$ $10^{.6}$ to $\left.67 \times 10^{.6} \mathrm{~cm} / \mathrm{s}\right)$ and averages $2.4 \times 10^{.2} \mathrm{ft} /$ day $\left(8.5 \times 10^{.6} \mathrm{~cm} / \mathrm{s}\right)$.

The average linear groundwater velocity of the Navajo Sandstone is also considerably lower than that of the alluvium. The calculated average linear groundwater velocity in the Navajo Sandstone is $1 \mathrm{ft} / \mathrm{yr}\left(1 \times 10^{-6} \mathrm{crn} / \mathrm{s}\right)$, based on an average hydraulic conductivity of $2.4 \times 10^{.2} \mathrm{ft} /$ day $\left(8.5 \times 10^{.6} \mathrm{~cm} / \mathrm{s}\right)$ under a hydraulic gradient of 0.02 and an estimated effective porosity of 0.30 (Cooley et al., 1969).

\subsubsection{Background groundwater quality}

Background groundwater quality is defined as the quality of groundwater that would be expected at the site if uranium processing activities had not occurred. Water samples were collected from monitor wells located in areas hydraulically upgradient and cross gradient from the sites for chemical analysis. For the NC site, background groundwater quality has been determined for the Dolores River alluvium and the Navajo Sandstone. No monitor wells were screened in the Entrada Formation at the NC site. At the UC site, background groundwater quality has been determined for each of the three hydrostratigraphic units: Dolores River alluvium, Entrada Formation, and Navajo Sandstone. Detailed information is provided in Appendix $C$ to of this document, Calculation SRK-0593-14-10-00.

Background water quality was characterized by analyzing constituents listed in Table 8.1 of the Technical Approach Document (TAD) (DOE, 1989). For characterization purposes, background water quality is described by the average concentration in the sample data and a statistical maximum. The procedures for calculating average and statistical maximum concentrations are discussed in Statistical Analysis of Ground-Water Monitoring Data at RCRA Facilities-Interim Final Guidance (EPA, 1989) and are described in the TAD. Average concentrations of hazardous constituents are represented statistically by a mean or median, depending on the proportion of nondetects, the distribution of the water quality data, and the number of samples available. The following guidelines apply:

- If the coef cient of variation of the data is greater than one, the distribution is assumed to be lognormal and the geometric mean is reported.

- If the coefficient of variation of the data is less than one, the distribution is assumed to be normal and the arithmetic mean is reported.

- If more than 15 percent of the data are below detection, the median is reported. 
- If fewer than four samples are available, the median is reported.

Distribution types are unknown if fewer than four samples are reported.

The statistical maximum is the upper limit of the 98-percent confidence interval for the true average concentration assuming normal or lognormal distributions. A nonparametric upper confidence interval is used if more than 15 percent of the data are below detection. If fewer than four samples are reported, the maximum observed concentration is chosen as a statistical maximum. When the majority of data are below detection, the reported statistical maximum may be the detection limit divided by 2, as computed by the Software Program for Environmental Analysis and Reporting system (DOE, 1992). When the statistical values calculated are below the actual laboratory detection limits, the laboratory detection limits reported in Table 8.1 of the TAD (DOE, 1989) are applied.

\section{Background groundwater quality in the alluvium - North Continent site}

Two background monitor wells are screened and filter-packed in the Dolores River alluvium at the NC site. These monitor wells are identified as 501 and 686 (see Figure 3.1). Groundwater quality data by parameter are provided in Table 3.5 of Appendix $A$ and groundwater quality statistics are provided in Table 3.6 of Appendix A.

Review of the background groundwater analysis reveals the $\mathrm{pH}$ of groundwater in the Dolores River alluvium at the NC site ranges from 6.9 to 7.1 and averages 7.2. TDS concentrations measured in background monitor wells at the NC site range from $622 \mathrm{mg} / \mathrm{L}$ to $991 \mathrm{mg} / \mathrm{L}$. Background groundwater quality in the alluvial materials is characterized as a calcium-sodium sulfate type at both the NC and UC sites.

Table 3.7 of Appendix A summarizes regulated constituents, with and without MCLs, from NC background monitor well samples. MCLs of some regulated constituents have been exceeded in groundwater samples collected from the NC background monitor wells screened in the Dolores River alluvium. These exceedances are shown in Table 3.8 of Appendix $A$ and discussed below.

Molybdenum concentrations slightly exceeded the MCL $(0.1 \mathrm{mg} / \mathrm{L})$ once (July 1986) in a sample collected from monitor well 501 and twice (July 1986 and February 1988) in ground water samples collected from monitor well 686. The statistical maximum for molybdenum in groundwater samples collected from the NC alluvial background monitor wells is $0.13 \mathrm{mg} / \mathrm{L}$ which slightly exceeds the MCL for molybdenum.

Uranium concentrations have exceeded the $M C L(0.044 \mathrm{mg} / \mathrm{L})$ on three separate occasions in a one-year time frame (April 1987 to April 1988) in groundwater samples collected from monitor well 686. Furthermore, the statistical maximum for uranium is 0.048 , which exceeds the uranium $\mathrm{MCL}$. 
Ra-226 and -228 activities exceeded the MCL $[5.0$ picocuries per liter $(\mathrm{pCi} / \mathrm{L})]$ once in a sample collected from monitor well 501 in March 1991. The statistical maximum for Ra-226 and -228 equals this one-time exceedance $(7.48 \mathrm{pCi} / \mathrm{L})$ and exceeds the $5.0 \mathrm{pCi} / \mathrm{L} \mathrm{MCL}$ for Ra-226 and -228 . However, this radium exceedance appears suspect because the detected activity occurs completely in Ra-228 and because, aside from this one-time occurrence, Ra-228 has never exceeded $1.5 \mathrm{pCi} / \mathrm{L}$ at this location. Therefore, this exceedance may be the result of a laboratory analysis error rather than a true measurement of the Ra-228 activity.

\section{Background groundwater quality in the alluvium - Union Carbide site}

One background monitor well (505) has been used to characterize groundwater quality in the Dolores River alluvium at the UC site. Groundwater quality data by parameter are provided in Table 3.5 of Apper.dix $A$ and groundwater quality statistics are provided in Table 3.9 of Appendix $A$.

Based on the results of historical water quality monitoring at this location, the background $\mathrm{pH}$ ranges from 6.9 to 7.3 at the UC site. TDS concentrations measured in this background monitor well range from $875 \mathrm{mg} / \mathrm{L}$ to $1180 \mathrm{mg} / \mathrm{L}$.

Table 3.10 of Appendix A summarizes regulated constituents, with and without MCLs, from UC background monitor well samples. MCLs have been exceeded for the following constituents in groundwater samples collected from the UC alluvial background monitor well as shown in Table 3.8 of Appendix $A$.

Molybdenum either equaled or slightly exceeded its $M C L(0.1 \mathrm{mg} / \mathrm{L})$ in samples collected from monitor well 505 in July 1986 and February 1988. The statistical maximum for molybdenum $(0.11 \mathrm{mg} / \mathrm{L})$ in $U C$ background alluvial monitor wells slightly exceeds the $\mathrm{MCL}$.

Chromium exceeded the $\mathrm{MCL}(0.05 \mathrm{mg} / \mathrm{L})$ once in a sample collected from monitor well $505(0.07 \mathrm{mg} / \mathrm{L})$ in July 1986. However, this chromium exceedance appears suspect because chromium has not been detected at this sampling location, aside from this one-time occurrence. Therefore, this exceedance may be the result of a sample collection or analysis problem rather than a true measurement of the chromium concentration.

\section{Background groundwater quality in the Entrada Formation - Union Carbide site}

Background groundwater quality in the Entrada Formation has been characterized by monitoring two wells at the UC site (551 and 703).

Construction information for these two background monitor wells, screened and filter-packed in the Entrada Formation, is provided in Table 3.2 of Appendix A. Monitor well locations are shown in Figure 3.1. Groundwater quality data by parameter are provided in Table 3.11 of Appendix $A$ and groundwater quality statistics are provided in Table 3.12 of Appendix $A$. 
The $\mathrm{pH}$ of groundwater in the Entrada Formation is slightly alkaline ranging from 7.8 to 8.0. TDS concentrations measured in the Entrada Formation background monitor wells range from $147 \mathrm{mg} / \mathrm{L}$ to $1990 \mathrm{mg} / \mathrm{L}$. Background groundwater quality of the Entrada Formation is characterized as a calcium bicarbonate to sodium bicarbonate type.

Table 3.13 of Appendix A summarizes regulated constituents with and without MCLs from Entrada Formation background monitor well samples. Two hazardous constituents, Ra-226 and -228 and selenium, have exceeded their respective MCLs in groundwater samples collected from the background monitor wells screened in the Entrada Formation, as shown in Table 3.14 of Appendix A.

Ra-226 and -228 exceeded their MCLs $(5.0 \mathrm{pCi} / \mathrm{L}$ ) once (August 1991$)$ in a sample collected from monitor well 703. However, the statistical maxirilum for Ra-226 and -228 is below the MCL.

Selenium has exceeded its MCL $10.01 \mathrm{mg} / \mathrm{L}$ ) twice in four months (December 1990 to March 1991) in groundwater samples collected from monitor well 551. The statistical maximum for background groundwater quality in the Entrada Formation for selenium $(0.013 \mathrm{mg} / \mathrm{L})$ slightly exceeds the $\mathrm{MCL}$.

\section{Background groundwater quality in the Navajo Sandstone - North Continent site}

Background groundwater quality in the Navajo Sandstone was characterized by monitoring one well at the NC site (687), shown in Figure 3.1. Groundwater quality data by parameter are provided in Table 3.15 of Appendix $A$ and groundwater quality statistics are provided in Table 3.16 of Appendix A.

The $\mathrm{pH}$ of groundwater samples collected from background monitor wells screened in the Navajo Sandstone at the NC site ranges from 7.2 to 7.6. TDS concentrations range from $492 \mathrm{mg} / \mathrm{L}$ to $1530 \mathrm{mg} / \mathrm{L}$. Background groundwater quality in the Navajo Sandstone is characterized as a sodium bicarbonate type at the NC site.

Table 3.17 of Appendix A summarizes regulated constituents, with and without MCLs, from Navajo Formation background monitor well samples. MCLs for several hazardous constituents have been equaled or exceeded in groundwater samples collected from the background monitor well 687. The MCLs for chromium, molybdenum, Ra-226 and -228 , and uranium have been equaled or exceeded in NC Navajo Sandstone monitor well samples, as shown in Table 3.18 of Appendix A.

Chromium was reported to equal the $M C L(0.05 \mathrm{mg} / \mathrm{L}$ ) once (July 1986) in a sample collected from monitor well 687 at the NC site. However, this chromium exceedance appears suspect because 1) chromium has never been detected in any monitor wells screened in the Navajo Sandstone, aside from this one-time occurrence, and 2) the MCL for chromium also was exceeded in a 
one-time occurrence in a sample collected from a UC alluvial background monitor well on the same date. Therefore, this exceedance may result from a sample collection or analysis problem rather than from a true measurement of the chromium concentration.

Molybdenum exceeded the MCL $(0.1 \mathrm{mg} / \mathrm{L})$ in NC monitor well 687 on one occasion in 1986.

Ra-226 and -228 activities exceeded the MCL $(5.0 \mathrm{pCi} / \mathrm{L})$ in NC background Navajo Sandstone monitor well 687 on one occasion in 1991. The statistical maximum for Ra-226 and -228 activities at the $N C$ site $(5.2 \mathrm{pCi} / \mathrm{L})$ slightly exceeds the MCL.

Uranium was reported to exceed the $\mathrm{MCL}$ in one sample collected from monitor well 687 . However, the statistical maximum for uranium $(0.037 \mathrm{mg} / \mathrm{L})$ at the NC site does not exceed the MCL $10.044 \mathrm{mg} / \mathrm{L})$.

\section{Background groundwater quality in the Navajo Sandstone - Union Carbide site}

At the UC site, background groundwater quality in the Navajo Sandstone was characterized by monitoring two wells (668 and 558). Monitor well locations are shown in Figure 3.1. Groundwater quality data by parameter are provided in Table 3.15 of Appendix $A$ and groundwater quality statistics are provided in Table 3.19 of Appendix A.

The $\mathrm{pH}$ of groundwater measured in background monitor wells screened in the Navajo Sandstone ranges from 7.4 to 7.8 , at the UC site. TDS concentrations are generally lower at the UC site than at the NC site, where they range from $229 \mathrm{mg} / \mathrm{L}$ to $1160 \mathrm{mg} / \mathrm{L}$. Background groundwater quality in the Navajo Sandstone is characterized as a magnesium bicarbonate type at the UC site.

Table 3.20 of Appendix A summarizes regulated constituents, with and without MCLs, from Navajo Formation background monitor well samples.

Concentrations or activities of molybdenum, Ra-226 and -228 , selenium, and silver measured in UC Navajo Sandstone monitor well samples have also equaled or exceeded the respective MCLs, as shown in Table 3.18 of Appendix A.

Molybdenum exceeded the MCL $(0.1 \mathrm{mg} / \mathrm{L})$ in UC monitor well 668 . This is the same sampling round in which a molybdenum exceedance was reported for Navajo Sandstone monitor well 687 at the NC site.

Ra-226 and -228 activities exceeded the $M C L(5.0 \mathrm{pCi} / \mathrm{L})$ in all of the UC background Navajo Sandstone monitor wells on one or more occasions in 1991. The statistical maximum for Ra-226 and -228 activities at the UC site $(5.6 \mathrm{pCi} / \mathrm{L})$ slightly exceeds the $\mathrm{MCL}$. 
Selenium concentrations exceeded the MCL $(0.01 \mathrm{mg} / \mathrm{L})$ twice in 10 months (December 1991 to October 1992) in groundwater samples collected from monitor well 558 (UC site). The statistical maximum for background groundwater quality in the Navajo Sandstone $(0.025 \mathrm{mg} / \mathrm{L}$ for the UC site) exceeds the MCL for selenium.

Silver was reported to exceed the $M C L$ in a sample collected from monitor well 668 during the July 1986 sampling round. However, this reported value is suspect because silver has never been detected in any background monitor wells, aside from this one-time occurrence.

\subsubsection{Tailings and milling process characterization}

Contaminated materials cover an estimated 12 acres (ac) [4.9 hectares (ha)] of the NC site and $55 \mathrm{ac}(22 \mathrm{ha})$ of the UC site. Both processing sites have tailings piles and wind-and waterborne-contaminated areas. In addition, concrete foundations of mill buildings exist at the UC site. The estimated volume of contaminated materials for the NC and UC sites is provided in Table 1.1 of the remedial action selection report. In addition to the contamination in the two processing site areas, four properties off the site [vicinity properties (VP)] were found to be contaminated from uranium milling activities. Site-specific inforrnation for tailings characterization is provided below for both the NC and UC processing sites.

\section{North Continent processing site}

The original owner of the site was Shattuck Chemical Company. North Continent Mines Inc. acquired the site in 1934. A method of acid leaching was used un ore that averaged 0.28 percent $\mathrm{U}_{3} \mathrm{O}_{8}$ and 3 percent $\mathrm{V}_{2} \mathrm{O}_{5}$. The initial mill capacity was 10 to 15 tons/day $[9,070$ to 13,610 kilograms per day $(\mathrm{kg} / \mathrm{d})]$ (FBDU, 1977). In 1942, a rotary kiln roaster was installed and the mill converted to a salt roast process with acid leach to recover $V_{2} O_{5}, U_{3} O_{8}$, and a radium concentrate. Mill capacity was increased to 30 tons/day $(27,200 \mathrm{~kg} / \mathrm{d})$. Title was passed to several companies, including UC, the present owner, in 1957. An estimated 37,000 tons $\left(33.6 \times 10^{6} \mathrm{~kg}\right)$ of ore were processed during the mill lifetime, producing the same amount of tailings. Seepage from the NC tailings pile has entered the groundwater in the alluvium beneath the site.

All structures were removed after milling operations were discontinued in the early 1960 s. When the mill was dismantled, bricks removed from the roaster were buried in the tailings pile. The pile was contoured, covered with 6 inches (in) $(15 \mathrm{~cm})$ of soil, and vegetated.

Laboratory measu: arnents of water content in tailings samples indicate that much of the tailings are relatively dry sands (see Attachment 1 of this RAP). The NC tailings average residual volumetric moisture content is 5.1 percent (ranging from 4.6 to 6 percent). Laboratory saturated permeability tests 
indicate the NC tailings' saturated hydraulic conductivity is $133.2 \mathrm{ft} /$ day $(4.7 \mathrm{x}$ $10^{-2} \mathrm{~cm} / \mathrm{s}$ ).

The chemical characteristics of the tailings were evaluated by pore fluid sampling with suction lysimeters. Five lysimeters were placed in the NC tailings materials in November 1990 at the locations shown in Figure 3.1. Samples collected from the lysimeters were screened for the inorganic and radioactive hazardous constituents of concern, listed in Table 1.1 of Appendix A. In some instances, the quantities of tailings pore water collected from the lysimeters were insufficient to conduct all of the analytical laboratory tests. As a result, data for some inorganic and radionuclide parameters (i.e., nitrate, gross alpha, and Ra-226 and -228 ) that require large sample volumes may not be available. Tailings pore fluid quality by parameter is presented in Table 3.21 of Appendix A. Tailings pore fluid quality statistics by parameter are presented in Table 3.22 of Appendix $A$. Detailed information regarding the water-quality of the tailings pore fluid solution is presented in Calculation SRK-05-93-12-07-00, Appendix $C$, of this document.

Tailings pore fluid water quality data were evaluated by comparing the statistical averages of the source term to the following:

- The detection limits provided in Table 8.1 of the UMTRA TAD (DOE, 1989).

- The MCLs specified for inorganic and radionuclide species in 40 CFR 192.

- The statistical maximum of background groundwater quality at the Burro Canyon disposal site.

Regulated constituents in tailings pore fluid samples are summarized for the Slick Rock NC processing site in Table 3.23 of Appendix A. Samples collected from lysimeters at the NC site had insufficient sample volumes to conduct and/or provide statistical calculations (i.e., less than four analyses available per sampling location) for the following analytes: mercury, nitrate, Ra-226 and -228 , cyanide, and sulfide.

Concentrations of 10 inorganic hazardous constituents with MCLs, measured in the tailings pore fluid samples, exceeded the TAD laboratory method detection limit on one or more occasions. These constituents are arsenic, barium. cadmium, chromium, net gross alpha, lead, molybdenum, selenium, silver, and uranium. Concentrations of eight elements listed in the EPA proposed groundwater standards that exceed the laboratory method detection limit are antimony, beryllium, copper, nickel, thallium, tin, vanadium, and zinc.

Individual tailings pore fluid measurements that exceec MCLs are presented in Table 3.24 of Appendix A. Mean or median concentrations or activities of six hazardous constituents in tailings pore fluid exceeded the MCLs in lysimeter samples collected from the NC site. These constituents are arsenic, cadmium, molybdenum, net gross alpha, selenium, and uranium. Additionally, the median or mean concentrations of five hazardous constituents without MCLs exceeded 
the statistical maximum of background groundwater quality for the upper Burro Canyon Sandstone unit at the disposal site. These constituents are antimony, copper, tin, vanadium, and zinc.

\section{Union Carbide processing site}

The uranium processing mill became operational in September 1957 with a design capacity of 350 tons/day $(317,520 \mathrm{~kg} / \mathrm{d})$, and later expanded to 500 tons $/$ day $\left(453,600 \mathrm{~kg} / \mathrm{d}\right.$ ) (FBDU, 1977). Ore averaging 0.245 percent $\mathrm{U}_{3} \mathrm{O}_{8}$ and 1.35 percent $\mathrm{V}_{2} \mathrm{O}_{5}$ was delivered to the upgrader from Slick Rock area mines. Dry grinding and air sizing were used to produce a minus 14 -mesh product and recover a large portion of the fine fraction. The fine fraction constituted the first concentrate. The coarse-ore fraction was combined with recirculated acid solution; a sand-slime separation then was made on the slurry. The sand product was further acid-leached, washed, and discharged to tailings. The slimes were dewatered and dried as a second concentrate. A third product resulted from ammonia neutralization of part of the pregnant solution. All three products were shipped to UC's Rifle, Colorado, mill for additional processing. About 60 percent of the uranium was contained in the initial dry-fine product and an additional 30 to 35 percent in the other two products (Merritt, 1971).

The Slick Rock UC site ceased operations in December 1961. Approximately 350,000 tons $\left(317.5 \times 10^{6} \mathrm{~kg}\right)$ of tailings remain on the site; these sand tailings contain only a small portion of the residual radioactivity. The volume of tailings is provided in Table 1.1 of the remedial action selection report. The tailings pile was contoured, covered with 6 in $(15 \mathrm{~cm})$ of soil, and vegetated. The pile currently has vegetation covering 20 percent of the surface (FBDU, 1981). A small earth dike separates the pile from the Dolores River. However, the river has eroded the dike, affecting an estimated 25 percent of the stabilized pile and soil cover. Contamination extends downriver and across the mesa from the UC site. Seepage from the UC tailings piles has also entered the groundwater in the alluvium beneath the piles.

All mill buildings have been removed from the site, although concrete foundations are present. West of the mill area is an abandoned trailer park, a recreation facility, and a gas sweetener plant.

Tailings at the UC site have an average residual volumetric moisture content of 4.4 percent (ranging from 2.5 to 6.5 percent) (see Attachment 1). Laboratory saturated permeability tests indicate the UC tailings saturated hydraulic conductivity is $156 \mathrm{ft} /$ day $\left(5.5 \times 10^{.2} \mathrm{~cm} / \mathrm{s}\right)$.

To obtain samples of the tailings pore fluid for analysis, two field investigations were conducted to install lysimeters in the tailings pile. Three lysimeters were installed in January 1989. Six additional lysimeters were installed in November 1990. The locations of these lysimeters are shown on Figure 3.1. Tailings pore fluid quality by parameter is presented in Table 3.21 of Appendix A. Tailings pore fluid quality statistics by parameter are presented in Table 3.25 of 
Appendix $A$ and are summarized for the UC site in Table 3.26 of Appendix A. Detailed information regarding the water-quality of the tailings pore fluid solution is presented in Calculation SRK-05-93-12-07-00, in Appendix C, of this document. Samples collected from lysimeters at the UC site had insufficient sample volumes to conduct and/or provide statistical calculations (i.e., less than four analyses available per sampling location) for Ra-226 and -228 and cyanide.

Eight inorganic hazardous constituents with MCLs exceeded the laboratory method detection limits in UC tailings pore fluid samples on one or more occasions. These constituents are arsenic, barium, cadmium, molybdenum, net gross alpha, nitrate, selenium, and uranium. Concentrations of five potentially hazardous elements listed in the EPA proposed groundwater protection standards, and that exceed the laboratory method detection limit, are antimony, copper, tin, vanadium, and zinc.

Mean or median values for hazardous constituents in the tailings pore fluid were compared to the MCLs. Mean or median observed concentrations of five hazardous constituents in tailings pore fluid exceeded the MCLs as shown in Table 3.26 of Appendix A. These constituents are cadmium, molybdenum, nitrate, selenium, and uranium. For hazardous constituents with no MCLs, mean or median tailings pore fluid quality data were compared to the statistical maximum of the background groundwater quality for the upper Burro Canyon Sandstone unit at the disposal site. The median or mean concentrations of five hazardous constituents without MCLs exceed the statistical maximum concentrations for background groundwater quality. These constituents are antimony, copper, tin, vanadium, and zinc.

Both Slick Rock processing sites were screened for priority pollutants, pesticides, and additional regulated compounds. In July 1986, groundwater samples were collected from two on-site monitor wells: one at the NC site (503) and the other at the UC site (510). Toluene and di-n-butyl phthalate were detected in the groundwater sample collected from monitor well 503. However, these compounds were also detected in one or more of the accompanying field blanks in the same concentrations as were detected in well 503. Therefore, the detection of these compounds is most likely the result of laboratory contamination, since they were detected in both the monitor well sample and the accompanying field blanks. All of the organic compounds analyzed were below detection limits in the sample collected from monitor well 510 at the UC processing site.

\subsubsection{Extent of groundwater contamination}

Baseline groundwater quality is defined as the representative water quality in a monitor well that has been influenced by uranium processing activities (DOE, 1989). To assess the extent of groundwater contamination caused by leachate seepage from the tailings pile and from processing activities, baseline groundwater quality data were collected from 3 DOE monitor wells at the NC processing site and 11 DOE monitor wells at the UC processing site. On-site 
and downgradient monitor well locations are shown on Figure 3.1. The NC monitor wells $(503,504$, and 512) are all screened and filter-packed in the Dolores River alluvium. None of the NC monitor wells are screened exclusively in the Entrada Formation or in the Navajo Sandstone. Of the 11 on-site and downgradient monitor wells used for baseline groundwater characterization at the UC processing site, 5 monitor wells $(506,507,508,509$, and 510) are screened in the Dolores River alluvium, 3 monitor wells $(554,702$, and 704) are screened in the Entrada Formation, and 3 monitor wells $(669,670$, and 688) are screened in the Navajo Sandstone. Lithologic logs and construction information for these DOE monitor wells are provided in Appendix B.

\section{Baseline groundwater quality in the Dolores River alluvium - North Continent site}

Baseline groundwater quality data by parameter for on-site and downgradient monitor wells screened in the Dolores River alluvium at the NC site (monitor wells 503,504 , and 512 ) are provided in Table 3.27 of Appendix A. A statistical treatment of the baseline groundwater quality data is provided for the NC processing site in Table 3.28 of Appendix A. Detailed information for the baseline groundwater quality data of the Dolores River alluvium is provided in Calculation SRK-05-93-14-11 in Appendix C.

The $\mathrm{pH}$ of the baseline alluvial groundwater ranges from 6.8 to 7.2 in samples collected from NC monitor wells. TDS concentrations range from 1060 to $4300 \mathrm{mg} / \mathrm{L}$. The on-site/downgradient groundwater is predominantly a sodium-sulfate type. Groundwater samples influenced by seepage from the tailings at the processing site have a higher percentage of sulfate than is related to uranium processing.

As precipitation infiltrates through the tailings, contaminants seep into the alluvial groundwater and migrate horizontally and vertically from the site as a contaminant plume. The extent of groundwater contamination is indicated by the distribution of sulfate in the alluvial aquifer as shown in Figure 3.6. Sulfate is used to define the areal extent of a contaminant plume because it is a chemical by-product of the uranium ore processing activities at the Slick Rock sites and is present in groundwater at concentrations well above background. As indicated in Figure 3.6, the contaminant distribution represented by sulfate concentrations extends to the Dolores River.

Statistical procedures previously described in Section 3.1.5 were used to assess the baseline groundwater quality on the site and downgradient of the Slick Rock processing sites. A summary of regulated constituents in alluvial baseline groundwater is presented in Table 3.29 of Appendix A for alluvial NC monitor wells 503,504 , and 512 . Measured maximum values of the following six hazardous constituents exceed the MCLs in baseline alluvial groundwater at the NC site (Table 3.30 of Appendix A).

Chromium was reported as equal to its $\mathrm{MCL}(0.05 \mathrm{mg} / \mathrm{L})$ on one occasion (June 1986) in monitor well 503. However, this measured occurrence is not related to uranium processing activities because the average concentration of chromium measured in lysimeter samples does not exceed laboratory method 


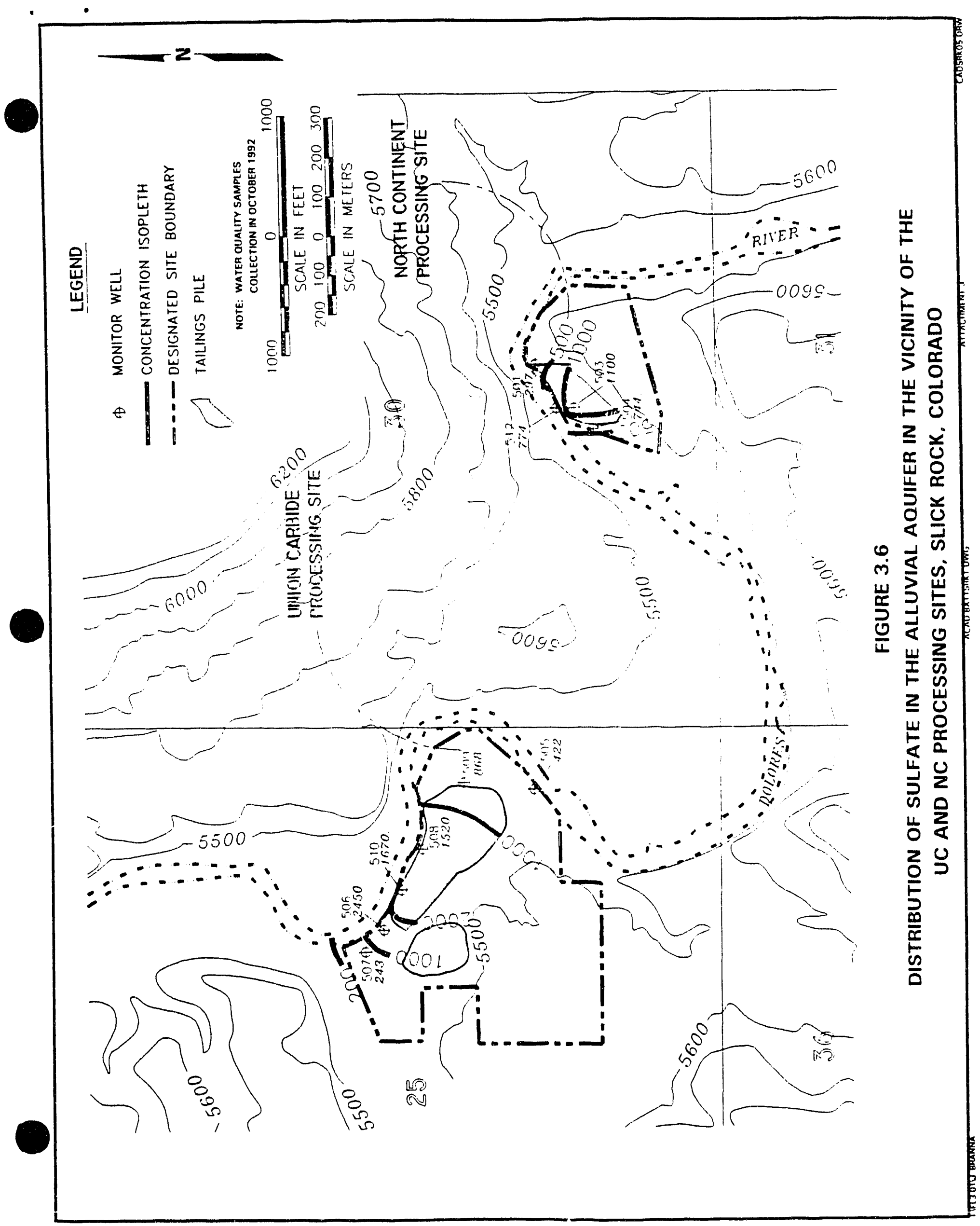


detection limit. Furthermore, because chromium has not been detected in any other historical sampling rounds, the reported concentration is probably an artifact of laboratory contamination rather than an accurate field measurement.

Molybdenum slightly exceeded the $M C L(0.10 \mathrm{mg} / \mathrm{L})$ once in each of the three baseline monitor wells (503 and 504 in February 1988, and 512 in July 1986). However, the statistical maximum of baseline alluvial groundwater $(0.04 \mathrm{mg} / \mathrm{L})$ is less than either the MCL or the statistical maximum of background alluvia: groundwater $(0.13 \mathrm{mg} / \mathrm{L})$. The alluvial background concentration exceeds thie $\mathrm{MCL}$ for molybdenum, most likely as a result of nearby localized ore deposits and mining activities. However, because the average concentration of molybdenum in the tailings pore fluid $(0.27 \mathrm{mg} / \mathrm{L})$ is twice the statistical maximum in background groundwater quality in the Dolores River alluvium, the uranium processing activities could have influenced the shallow groundwater quality downgradient of the NC processing site.

Net gross alpha activities have been reported to exceed the $M C L$ on numerous occasions, particularly in monitor well 504, as shown in Table 3.30 of Appendix $A$. The calculated baseline statistical maximum value for net gross alpha $(124 \mathrm{pCi} / \mathrm{L})$ significantly exceeds the $M C L(15 \mathrm{pCi} / L)$ and the calculated statistical maximum for alluvial background groundwater quality (5 $\mathrm{pCi} / \mathrm{L}$ ). Therefore, elevated concentrations of net gross alpha activities are expected in groundwaters downgradient from uranium processing activities at the NC site.

Ra-226 and -228 activities slightly exceeded their MCL in monitor well 512 on two occasions in 1991. Not enough tailings pore water was available to measure the activity of Ra-226 and -228 in the lysimeter samples. However, the background statistical maximum calculated for Ra-226 and -228 $(7.80 \mathrm{pCi} / \mathrm{L})$ exceeds the $\mathrm{MCL}(5.0 \mathrm{pCi} / \mathrm{L})$, as well as the baseline statistical maximum (3.69 $\mathrm{pCi} / \mathrm{L})$. Therefore, the observed values may be due to natural processes.

Selenium concentrations slightly exceeded the $M C L$ in baseline monitor wells 503 and 504 in May 1990, as shown in Table 3.30 of Appendix A. The baseline statistical maximum value for selenium $(0.015 \mathrm{mg} / \mathrm{L})$ slightly exceeds the MCL $(0.01 \mathrm{mg} / \mathrm{L})$ and exceeds the calculated statistical maximum for alluvial background groundwater quality $(0.005 \mathrm{mg} / \mathrm{L})$. Therefore, selenium contamination appears to have resulted from uranium processing activities at the NC site.

Uranium concentrations historically have significantly exceeded the $\mathrm{MCL}$ for uranium $(0.044 \mathrm{mg} / \mathrm{L})$ in both baseline and background sample populations. For alluvial groundwater at the NC site, the baseline statistical maximum is $3.183 \mathrm{mg} / \mathrm{L}$ and the background statistical maximum is $0.048 \mathrm{mg} / \mathrm{L}$. The average uranium concentration calculated for the NC lysimeter samples $(1.77 \mathrm{mg} / \mathrm{L})$ is also above the $\mathrm{MCL}$ for uranium. Therefore, although the background vater quality data indicate that the alluvial groundwater has elevated uranium concentrations of uranium upgradient of the processing site, 
uranium concentrations in groundwater have also been affected by on-site uranium processing activities.

Measured maximum concentrations of nine elements listed as hazardous constituents in the EPA's proposed groundwater protection standards (EPA, 1987) have equaled or exceeded the statistical maximum values of alluvial background groundwater: antimony, copper, cyanide, nickel, sulfide, thallium, tin, vanadium, and zinc. However, only cyanide, sulfide, and tin have baseline statistical maximum values greater than the corresponding background statistical maximum values. Exceedances of these three constituents are discussed below.

Cyanide was reported to only slightly exceed the detection limit $(0.01 \mathrm{mg} / \mathrm{L})$ by one measured unit (i.e., a measured concentration of $0.02 \mathrm{mg} / \mathrm{L}$ ) on one occasion. All other analyses of cyanide were below detection limits. As a result, this slight exceedance of the detection limit is considered suspect, and cyanide is not considered to be a hazardous constituent of concern.

Sulfide concentrations exceeded the alluvial background groundwater statistical maximum once (March/April 1991) in each baseline monitor well. These exceedances were slight in two of the wells $(503$ and 504) and over an order of magnitude high in one well (512). All of these wells have been sampled and analyzed for sulfide on three separate occasions since the exceedances were noted; they have all remained within the range of background since the reported exceedances. Furthermore, these occurrences do not appear to be related to uranium processing activities because the average concentration of sulfide measured in lysimeter samples is below the statistical maximum concentration in background groundwater.

Tin concentrations slightly exceeded the alluvial background groundwater statistical maximum once (May 1990) in two baseline monitor wells (503 and 504). The baseline statistical values reported in Table 3.28 of Appendix $A$ are ultraconservative because the highest reported detection limits, as well as measured values, are included in the statistical calculations. Monitor wells 503 and 504 were sampled and analyzed for tin on four separate occasions since the exceedances were noted; they have remained less than the detection limits since the reported exceedances. Furthermore, these occurrences do not appear to be related to uranium processing activities because the average concentration of tin measured in lysimeter samples is below the statistical maximum concentration in background groundwater.

\section{Baseline groundwater quality in the Dolores River alluvium - Union Carbide site}

Baseline groundwater quality data by parameter for on-site and downgradient monitor wells screened in the Dolores River alluvium at the UC site (monitor wells 506 through 510 ) are provided in Table 3.27 of Appendix A. A statistical treatment of the baseline groundwater quality data is provided for the UC processing site in Table 3.31 of Appendix A. Detailed information for the 
baseline groundwater quality data of the Dolores River alluvium is provided in Calculation SRK-05-93-14-11-00 of Appendix C.

At the Slick Rock UC processing site, the $\mathrm{pH}$ of the baseline alluvial groundwater ranges from 6.1 to 7.3. This is slightly more acidic than in UC background monitor wells. On-site and downgradient TDS concentrations range from 259 to $9560 \mathrm{mg} / \mathrm{L}$. TDS concentrations for background groundwater at the UC site range from 875 to $1180 \mathrm{mg} / \mathrm{L}$. The on-site/downgradient groundwaters are calcium sulfate and sodium sulfate types.

Statistical procedures described in Section 3.1 .5 were used to assess the baseline groundwater quality on the site and downgradient of the Slick Rock processing sites. Table 3.32 of Appendix A summarizes baseline groundwater quality data for UC alluvial monitor wells (506 through 510). Measured maximum values of the following eight hazardous constituents exceed the MCLS in baseline alluvial groundwater at the UC site (Table 3.30 of Appendix A).

Cadmium exceeded its MCL $10.05 \mathrm{mg} / \mathrm{L}$ ) once (October 1992) in monitor well 508. This measured occurrence was the first time cadmium was detected in monitor well 508. The average concentration of cadmium measured in lysimeter samples was four times greater than the MCLs. Therefore, this exceedance may be related to uranium mine tailings.

Chromium was reported equal to its MCL $(0.05 \mathrm{mg} / \mathrm{L}$ ) once (July 1986) in monitor well 510. However, this occurrence is not related to uranium processing activities because the average concentration of chromium measured in lysimeter samples does not exceed the laboratory method detection limit. Furthermore, because chromium has not been detected in any other historical sampling rounds, the reported concentration may be an artifact of laboratory contamination rather than an accurate field measurement.

Molybdenum frequently exceeds the $\mathrm{MCL}(0.10 \mathrm{mg} / \mathrm{L})$ in all of the $U C$ baseline monitor wells. A molybdenum isopleth map for the alluvial aquifer is presented in Figure 3.7. The statistical average of baseline alluvial groundwater $(0.23 \mathrm{mg} / \mathrm{L})$ exceeds the $\mathrm{MCL}$ and the statistical maximum of background alluvial groundwater $(0.11 \mathrm{mg} / \mathrm{L})$. The alluvial background concentration exceeds the MCL for molybdenum, probably as a result of nearby ore deposits and mining activities unrelated to the Uranium Mill Tailings Remedial Action (UMTRA) Project. The average concentration of molybdenum in the tailings pore fluid $(3.63 \mathrm{mg} / \mathrm{L})$, collected from lysimeters at the UC site, is over an order of magnitude greater than the statistical maximum of background groundwater quality in the Dolores River alluvium, indicating that the uranium processing activities have influenced the shallow groundwater quality downgradient of the UC processing site.

Net gross alpha activities have been reported to exceed the $M C L$ on numerous occasions, as shown in Table 3.30 of Appendix A. The calculated baseline statistical maximum value for net gross alpha $(48.79 \mathrm{pCi} / \mathrm{L})$ significantly exceeds the $\mathrm{MCL}(15 \mathrm{pCi} / \mathrm{L})$ and the maximum observed activity $(5.08 \mathrm{pCi} / \mathrm{L})$ of net gross alpha for alluvial background groundwater quality at the UC site. 


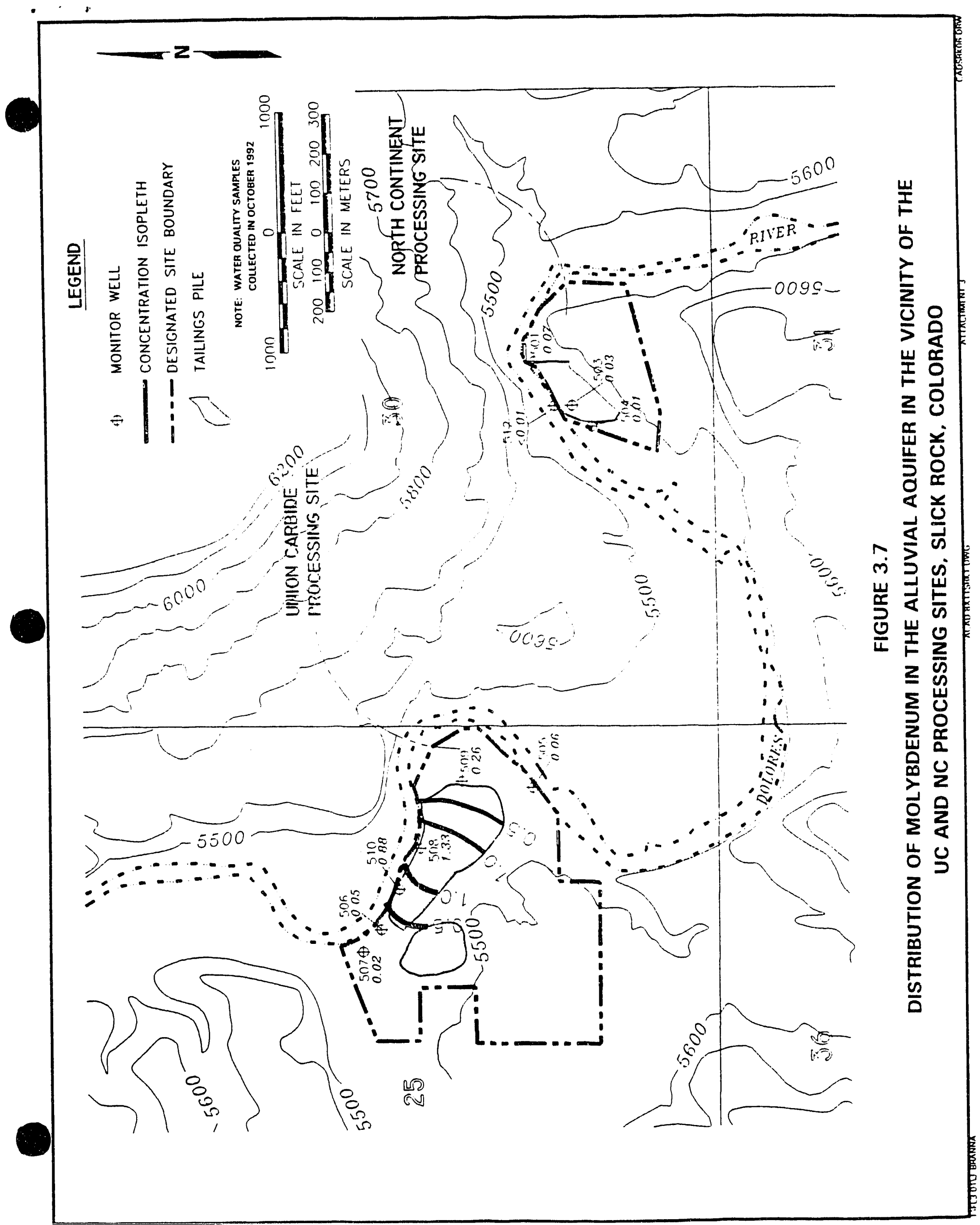


Therefore, elevated net gross alpha activities are probably the result of uranium processing activities at the UC site.

Nitrate concentrations have significantly and regularly exceeded the $\mathrm{MCL}$ $(44.0 \mathrm{mg} / \mathrm{L})$, particularly in UC monitor wells 508 and 510 . A nitrate isopleth for the alluvial aquifer is presented in Figure 3.8. The average concentration of nitrate in the tailings pore fluid $(210.0 \mathrm{mg} / \mathrm{L})$ collected from lysimeters at the UC site is three times greater than the MCL and over an order of magnitude greater than the statistical maximum of alluvial background groundwater quality 112.0 $\mathrm{mg} / \mathrm{L}$ ), indicating that uranium processing activities have influenced the quality of shallow groundwater downgradient of the UC processing site.

Ra-226 and -228 activities slightly exceeded the $M C L(5.0 \mathrm{pCi} / L)$ in three UC alluvial monitor wells $(506,508$, and 509). Not enough tailings pore water was available to measure the activity of Ra-226 and -228 in the lysimeter samples. The background statistical maximum calculated for Ra-226 and -228 $(2.33 \mathrm{pCi} / L)$ is within the same range as the baseline statistical maximum (2.10 pCi/L).

Selenium concentrations frequently exceed the MCL in UC baseline monitor wells. The baseline statistical maximum value for selenium $(0.065 \mathrm{mg} / \mathrm{L})$ exceeds the MCL $(0.01 \mathrm{mg} / \mathrm{L})$ and the calculated statistical maximum for alluvial background groundwater quality $(0.007 \mathrm{mg} / \mathrm{L})$. Therefore, elevated concentrations of selenium are expected to result from uranium processing activities at the UC site.

Uranium concentrations historically have exceeded the $M C L$ for uranium $(0.044 \mathrm{mg} / \mathrm{L})$ in the baseline UC alluvial groundwater samples. A uranium isopleth for the alluvial aquifer is presented in Figure 3.9. The baseline statistical maximum is $0.088 \mathrm{mg} / \mathrm{L}$, twice the $\mathrm{MCL}$. The background statistical maximum is $0.033 \mathrm{mg} / \mathrm{L}$ for alluvial groundwater at the UC site. The average uranium concentration calculated for the NC lysimeter samples $(0.26 \mathrm{mg} / \mathrm{L})$ is also above the MCL for uranium. Therefore, uranium concentrations in shallow groundwater have been affected by on-site uranium processing activities. Measured maximum concentrations of eight elements listed as hazardous constituents in the proposed EPA groundwater protection standards (EPA, 1987) equaled or exceeded the statistical maximum background values. These are antimony, copper, nickel, sulfide, thallium, tin, vanadium, and zinc. However, only thallium and vanadium have baseline statistical maximum values that are greater than the corresponding background statistical maximum values. Exceedances of these two constituents are discussed below.

Thallium has ultraconservative baseline statistical values because the highest reported detection limits, as well as measured values, are included in the statistical calculations. In fact, thallium has never been detected in any of the UC baseline monitor wells. Similarly, thallium has not been detected in the UC tailings pore fluid. Therefore, thallium is not a hazardous constituent of concern. 


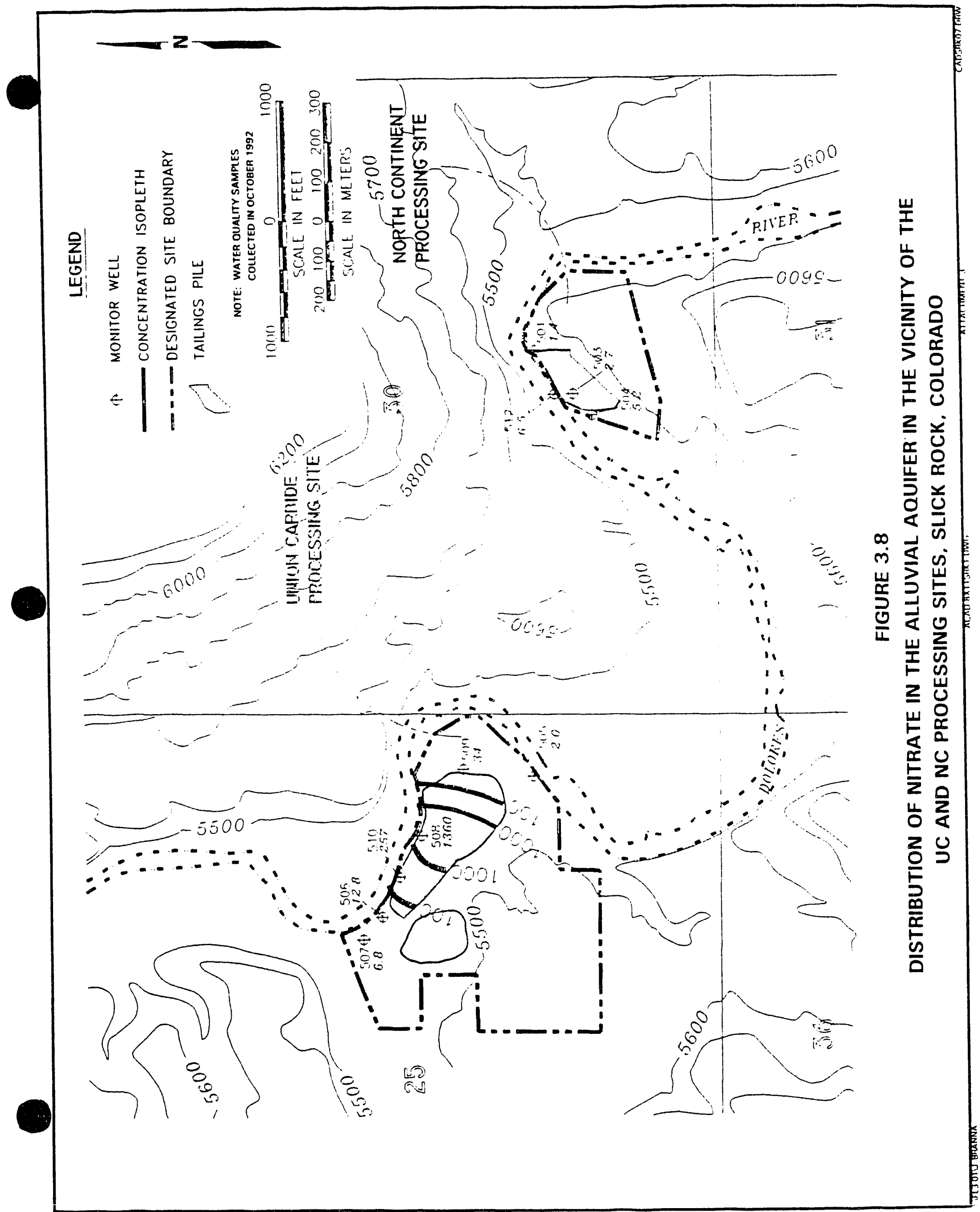




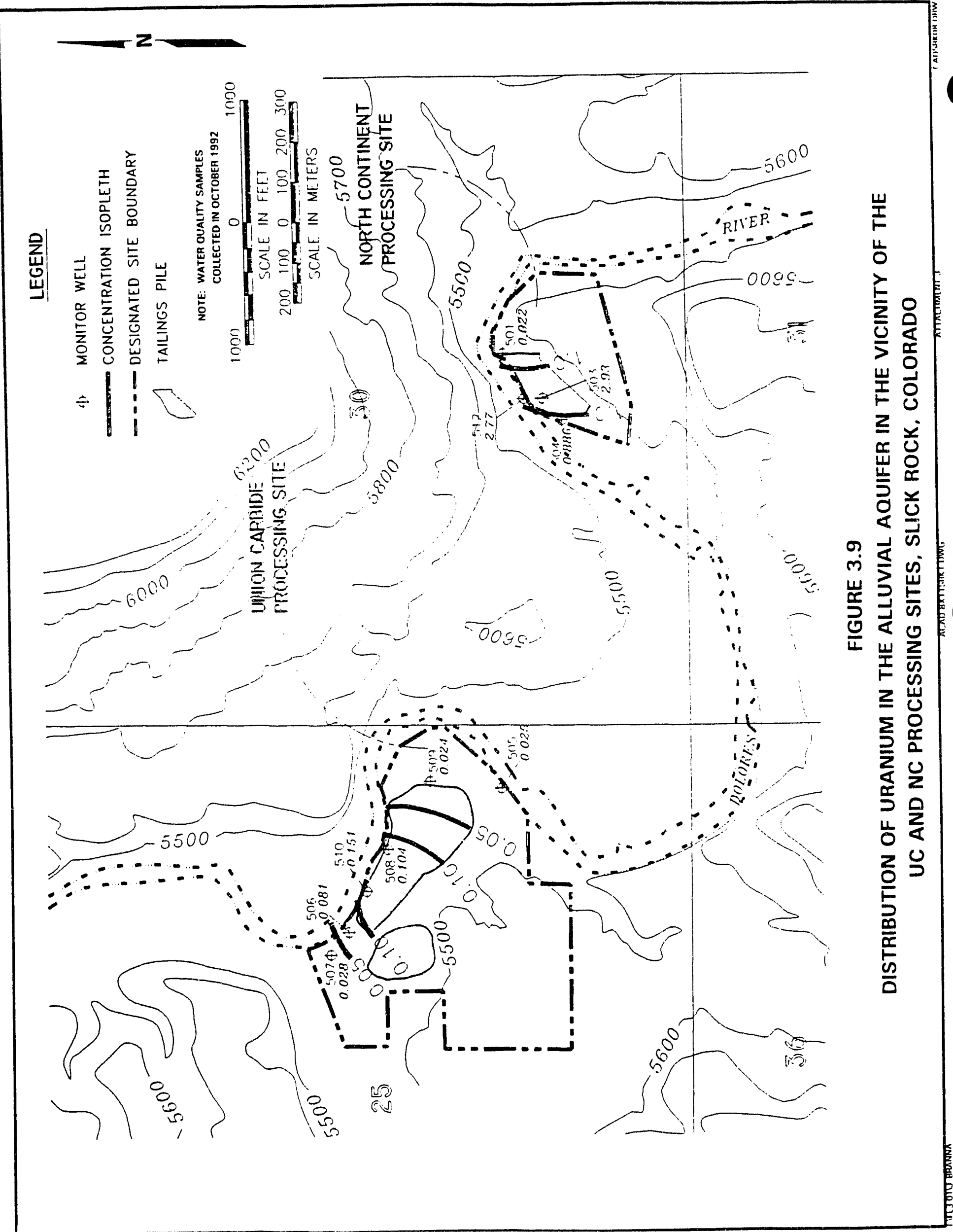


Vanadium concentrations have exceeded the statistical maximum for background alluvial groundivater. The baseline statistical maximum $(0.33 \mathrm{mg} / \mathrm{L})$ slightly exceeds the background statistical maximum $(0.24 \mathrm{mg} / \mathrm{L})$. The average concentration of vanadium in the UC tailings pore fluid is $0.18 \mathrm{mg} / \mathrm{L}$, less than the statistical maximum of background. Therefore, the somewhat elevated baseline vanadium concentrations may reflect natural variation in background concentrations and may be unrelated to uranium processing activities.

\section{Baseline groundwaiar quality in the Entrada Formation - Union Carbide site}

Baseline groundwater quality in the Entrada Formation at the UC site was characterized by monitoring three wells $(554,702$, and 704). Construction information for these three baseline monitor wells, screened and filter-packed in the Entrada Formation, is provided in Table 3.2 of Appendix A. Baseline groundwater quality data by parameter for on-site and downgradient monitor wells screened in the Entrada Formation are provided in Table 3.33 of Appendix A. A statistical treatment of the baseline groundwater quality data is provided for the UC processing site in Table 3.34 and summarized in Table 3.35 of Appendix A. None of the NC monitor wells are screened in the Entrada Formation. However, because the UC and NC processing sites are within a mile of each other and have very similar hydrostratigraphic and chemical characteristics, the baseline groundwater quality of the Entrada Formation at the UC site is expected to be representative of that at the NC site. Detailed water-quality information for the baseline water-quality of the Entrada Formation is provided in Calculation SRK-05-93-14-71-00 in Appendix C.

The $\mathrm{pH}$ of the baseline groundwater flowing through the Entrada Formation ranges from 6.9 to 8.0. TDS concentrations range from 412 to $2650 \mathrm{mg} / \mathrm{L}$. The on-site/downgradient Entrada groundwaters are predominantly calcium bicarbonate and magnesium bicarbonate, although monitor well 554 has a magnesium chloride water.

In five hazardous constituents, measured concentrations or activities exceeded the MCL on one or more occasion: barium, net gross alpha, nitrate, selenium, and uranium, as shown in Table 3.36 of Appendix A. Of these, only nitrate and selenium have calculated baseline statistical maximum values that exceed the MCLs.

Nitrate concentrations average $84.6 \mathrm{mg} / \mathrm{L}$ in monitor well 702 , and routinely exceeded the $\mathrm{MCL}(44.0 \mathrm{mg} / \mathrm{L})$, while concentrations in monitor wells 554 and 704 historically averaged $1.0 \mathrm{mg} / \mathrm{L}$ and $10.0 \mathrm{mg} / \mathrm{L}$. Nitrate concentrations also significantly exceeded the $\mathrm{MCL}$ in samples collected from the lysimeters and alluvial groundwater monitor wells. As a result, the elevated concentrations of nitrate detected in monitor well 702 are probably related to uranium processing activities.

Selenium routinely exceeded its MCL $(0.01 \mathrm{mg} / \mathrm{L})$ in samples collected from monitor wells 702 and 704 . The selenium statistical maximum for background 
groundwater quality in the Entrada Formation $(0.013 \mathrm{mg} / \mathrm{L})$ slightly exceeds the $\mathrm{MCL}$. Selenium crricentrations also exceeded the $\mathrm{MCL}$ in lysimeter and baseline alluvial groundwater samples. As a result, elevated selenium concentrations in the Entrada Formation at the UC processing site may be related to uranium processing activities.

Measured maximum concentrations of five elements listed as hazardous constituents in proposed EPA groundwater protection standards (EPA, 1987) equaled or exceeded the statistical maximum background values: sulfide, thallium, tin, vanadium, and zinc. However, only sulfide, tin, and zinc have baseline statistical maximum values that are greater than the corresponding background statistical maximum values, as shown in Table 3.35 of Appendix A. Exceedances of these three constituents are discussed below.

Sulfide resulting from uranium processing could have seeped into the Entrada Formation while the sulfide remaining in the tailings was oxidized to sulfate. Therefore, exceedances may be related to processing activities.

Tin has baseline statistical values that are ultraconservative because the highest reported detection limits, as well as measured values, are included in the statistical calculations. In fact, tin has never been detected in any of the UC baseline monitor wells. Therefore, tin is not a hazardous constituent of concern.

Zinc concentrations slightly exceeded the statistical maximum for background alluvial ground water in baseline monitor wells 702 and 704, on one or more cccasions. The baseline statistical maximum $(0.01 \mathrm{mg} / \mathrm{L})$ exceeds the background statistical maximum $(0.005 \mathrm{mg} / \mathrm{L})$.

\section{Baseline groundwater quality in the Navajo Sandstone - Union Carbide site}

Baseline groundwater quality in the Navajo Sandstone was characterized by monitoring three wells at the UC site $(669,670$, and 688). Monitor well locations are shown in Figure 3.1. Groundwater quality data by parameter are provided in Table 3.37 of Appendix $A$ and groundwater quality statistics are provided in Table 3.38 of Appendix A. Table 3.39 of Appendix A summarizes regulated constituents in the Navajo Sandstone baseline groundwater.

The $\mathrm{pH}$ of groundwater measured in baseline monitor wells screened in the Navajo Sandstone ranges from 7.0 to 8.9 at the UC site. TDS concentrations range from $222 \mathrm{mg} / \mathrm{L}$ to $1760 \mathrm{mg} / \mathrm{L}$. Baseline groundwater quality in the Navajo Sandstone is characterized as a calcium bicarbonate type.

Three hazardous constituent measurements equaled or exceeded the MCLs in groundwater samples collected from the baseline Navajo Sandstone monitor wells, as shown in Table 3.40 of Appendix A. These hazardous constituents include molybdenum, Ra-226 and -228 , and uranium. However, these observed exceedances are infrequent. The suminary of regulated constituents provided in 
Table 3.39 of Appendix A shows that all of these constituents have statistical maximum values below the MCLs.

Measured maximum concentrations of three elements listed as hazardous constituents in proposed EPA groundwater protection standards (EPA, 1987) have equaled or exceeded the statistical maximum background values. These are antimony, vanadium, and zinc. Of these constituents, only zinc has a baseline statistical maximum value greater than the corresponding background statistical maximum value, as shown in Table 3.39 of Appendix $A$.

Concentrations of zinc exceeded Navajo Sandstone background statistical maximum value in each of the three baseline monitor wells on one or more occasions.

\subsubsection{Geochemical conditions}

Geochemical conditions that control the transport of the hazardous constituents from the tailings into ground water and by groundwater within the aquifers at the processing site include 1) the chemical composition, $\mathrm{pH}$, and Eh of the tailings pore fluid, soil pore fluid, and groundwater; and 2) the reactive mineralogy of the subsoils and aquifer materials. The chemical compositions, $\mathrm{pH}$, and $\mathrm{Eh}$ of the various fluids determine the types of precipitation/coprecipitation reactions that can occur to control the migration rate of contaminants of concern. The chemical compositions, $\mathrm{pH}$, and $\mathrm{Eh}$ of the fluids combined with the reactive mineralogy of the subsoils and aquifer materials determine the types of adsorption reactions that can occur involving contaminants of concern.

Precipitation and coprecipitation reactions can result from 1) acid-neutralization reactions, 2) a general condition of oversaturation in the tailings seepage, and 3 ) oxidation-reduction reactions. The acid-neutralization reactions occur as a result of the seepage of tailings leachate into subsurface units containing carbonates and other acid-neutralizing phases. Neutralization of acid leachate causes the precipitation of metals originally in the leachate. Because the tailings fluids at the UC and NC sites are near-neutral in pH (5.9 to 7.9), acid-neutralization reactions will not be a major retardation mechanism for the contaminants of concern at the processing site.

The tailings pore fluids are generally oversaturated in gypsum, calcite, quartz and, locally, other solid phases. Although such oversaturation eventually leads to precipitation, the precipitation reactions commonly are slow to occur. In general, quartz precipitation rates are much slower than gypsum rates at the same level of oversaturation. Therefore, gypsum tends to precipitate from oversaturated solutions before quartz. As these phases precipitate in the pore spaces of the aquifers, some trace contaminants of concorn may coprecipitate with them, depending on the saturation level of the contaminant species. For example, radium could precipitate with gypsum or barite and cadmium and zinc could coprecipitate with calcite. 
The oxidation-rediction precipitation reactions are the most important class of precipitation reactions at the processing sites. In many cases, either the oxidized or reduced form of a contaminant or major ion is much more insoluble than the other form. For example, the oxidized form of uranium $\left(U^{+6}\right)$ is much more soluble than the reduced form $\left(U^{+4}\right)$. Conversely, the reduced forms of iron $\left(\mathrm{Fe}^{+2}\right)$ and manganese $\left(\mathrm{Mn}^{+2}\right)$ are much more soluble than the oxidized forms $\left(\mathrm{Fe}^{+3}\right.$ and $\left.\mathrm{Mn}^{+4}\right)$.

The geochemical parameter that gauges whether a given constituent is in an oxidized or reduced form is Eh. The Eh and several related parameters were measured ir, most wells at the NC and UC sites. In general, the wells in the alluvial aquifers immediately downgradient of the tailings piles (i.e., monitor wells 503 and 504 at the NC site and monitor wells 506 and 507 at the UC site) show low to moderately reducing conditions [ 80 to 280 millivolts (mV)]. In addition, one monitor well screened in the Entrada Formation downgradient of the mill area at the UC site (well 554) also shows reducing conditions (100 $\mathrm{mV}$ ). Oxidizing conditions (i.e., $>400 \mathrm{mV}$ ) are found in most of the other wells at both sites.

The reducing conditions in waters immediately downgradient from the NC and UC sites could immobilize selenium and uranium on the aquifer matrix. The reducing conditions will also maintain nitrogen in the form of ammonium instead of nitrate or nitrite. On the other hand, the mobility of iron and manganese will be enhanced by the reducing conditions. However, as the reducing groundwaters mix with oxidizing waters downgradient, the iron and possibly the manganese wili be oxidized and precipitate out of solution. As iron precipitates out of solution it could cleanse the water of other contaminants through coprecipitation and adsorption reactions.

As the reducing conditions in the alluvial aquifers return to naturally oxidizing conditions, the contaminants that were immobilized by reduction precipitation reactions may be remobilized, depending on the oxidation potential achieved in the aquifer. For example, any uranium immobilized by reduction will undoubtedly be remobilized. Selenium and nitrogen may or may not be converted to more mobile species, depending on the natural oxidation potential in the aquifer.

Adsorption reactions involve the attachment of simple and complex ions to the exterior surfaces of minerals in the aquifer matrix and/or ion exchange on interior exchange sites. Although the details of the surface attachment reactions are not completely known, it is well known that surfaces of iron and manganese oxides and oxyhydroxides have a high affinity for transition metals and oxyanions such as molybdate. The metals and oxyanions do not all have the same affinity for these oxides and oxyhydroxides. Based on theoretical derivations, the relative affinities cannot be reliably predicted in complex natural systems such as the groundwater associated with uranium mill tailings sites. These relative affinities must be measured in a laboratory by either batch or column experiments.

The ion exchange reactions are better understood and largely involve cation exchange. However, even the relative affinities of mineral phases for cationic 
contaminants such as Ra-226, cadmium, and zinc must be determined experimentally in batch and/or column experiments.

\subsubsection{Groundwater use, value, and alternative supplies}

Eleven domestic wells are registered in the vicinity of the Slick Rock tailings sites. Nine of these wells are no longer in use. One of these nine wells completed in the Navajo Sandstone, the Entrada Formation, and the alluvium is potentially available to supply drinking water to a gas sweetener plant that is adjacent to the UC site. The other well, completed in the Navajo Sandstone, currently supplies water to Slick Rock businesses and is upgradient of the NC and $U C$ processing sites. An unregistered well completed in the Navajo Sandstone supplies water to a local resident. All these wells are hydrologically upgradient from the UC tailings site. A groundwater flow boundary appears to follow the course of the Dolores River and is expected to hydrologically separate the active unregistered well from the NC tailings, which are on the opposite side of the Dolores River from the unregistered well. As a result, none of these wells are expected to be affected by the tailings materials at the Slick Rock processing sites.

Surface water from the Dolores River is another potential source of water in the vicinity of the processing site. Rights to this surface water will be secured before surface water from the Dolores River may be used during surface remedial action construction.

\subsection{DISPOSAL SITE}

\subsubsection{Previous investigations}

Three previous site-specific hydrologic investigations were conducted in the vicinity of the Burro Canyon disposal site. In 1985, preliminary testing was conducted southeast of the current Burro Canyon disposal site location. These initial site characterization activities consisted of excavating eight test pits and three boreholes to determine whether the location was suitable as a relocated disposal site. The area was found to be suitable for tailings disposal, as reported in the Comparative Analysis of Disposal Site Alternatives Report for the UMTRA Project Slick Rock Site Located at Slick Rock, Colorado (DOE, 1986).

A second detailed site investigation was conducted during 1990 and 1991 at the current Burro Canyon site. During 1990, the DOE installed 14 monitor wells, 4 boreholes, and 13 test pits to characterize lithology, groundwater elevations and hydraulic gradients, aquifer properties, and groundwater quality at the disposal site.

Additional testing was conducted in 1991 in response to two issues raised by the Colorado Department of Health: 1) the extent of the mudstone aquitard between the upper and middle sandstone units of the Burro Canyon Formation southeast (downgradient) of the proposed disposal site, and 2) the degree of 
downgradient saturation in the upper sandstone unit. An exploration corehole was drilled approximately $900 \mathrm{ft}(300 \mathrm{~m})$ from the edge of the disposal cell and to a total depth of $179 \mathrm{ft}(54 \mathrm{~m})$ bls. The corehole confirmed that the Burro Canyon mudstone and sandstone units were continuous. A monitor well was placed approximately $10 \mathrm{ft}(3 \mathrm{~m})$ north of the exploration corehole and was completed to the base of the upper Burro Canyon sandstone unit for a total depth of $113 \mathrm{ft}(34 \mathrm{~m})$. A second monitor well, placed approximately $650 \mathrm{ft}$ $(198 \mathrm{~m})$ southeast of the edge of the proposed disposal cell, was drilled through the upper sandstone unit [from 72 to $101 \mathrm{ft}(22$ to $31 \mathrm{~m})$ ], the mudstone aquitard [from 101 to $169 \mathrm{ft}(31$ to $52 \mathrm{~m})$ ], and $10 \mathrm{ft}(3 \mathrm{~m})$ into the middle sandstone unit for a total depth of $179 \mathrm{ft}(54 \mathrm{~m})$. This well was then backfilled with bentonite and a screen was installed at the base of the upper sandstone unit from 80 to $100 \mathrm{ft}(24$ to $30 \mathrm{~m})$, with filter pack material from 65 to $102 \mathrm{ft}$ $(20$ to $31 \mathrm{~m})$. Geophysical logs (natural gamma, gamma-gamma, neutron, and resistivity) were run in the exploratory borehole and five DOE monitor wells.

The locations of the monitor wells and piezometers are shown on Figure 3.10. Monitor well information is presented in Table 3.41 of Appendix $A$. In the following discussion, all depths recorded are measured from ground surface. Lithologic logs and monitor well construction information are provided in Appendix $B$ to Attachment 3.

The chemical and mineralogical properties of Burro Canyon sediment samples were characterized in 1990 by Pittsburgh Mineral \& Environmental Technology, Inc. (PMET, 1990). Sediment samples were collected from the Dakota Sandstone Formation (sandstones and shales) and from Burro Canyon Formation (mudstones and sandstones). The laboratory work included chemical analyses, polarized light microscopy with modal analyses, and $X$-ray diffraction analyses.

Relatively undisturbed samples were recovered for visual inspection and laboratory tests to determine unsaturated hydraulic conductivity, porosity, and other selected parameters. Five sediment samples were collected from mudstones and claystones of the Burro Canyon Formation. Laboratory analyses were conducted to determine moisture contents, bulk densities, porosities, saturated hydraulic conductivities, soil moisture retention curves, and particle densities (Daniel B. Stephens \& Associates, Inc., 1991).

Groundwater elevations were measured to map the potentiometric surface to determine the direction of groundwater flow and hydraulic gradients. Bailer recovery tests, aquifer performance tests, and slug injection tests were performed to measure hydraulic parameters of the upper, middle, and lower Burro Canyon sandstone units. Water quality samples were collected from selected wells in the Burro Canyon sandstone units to establish background water quality at the disposal site. 


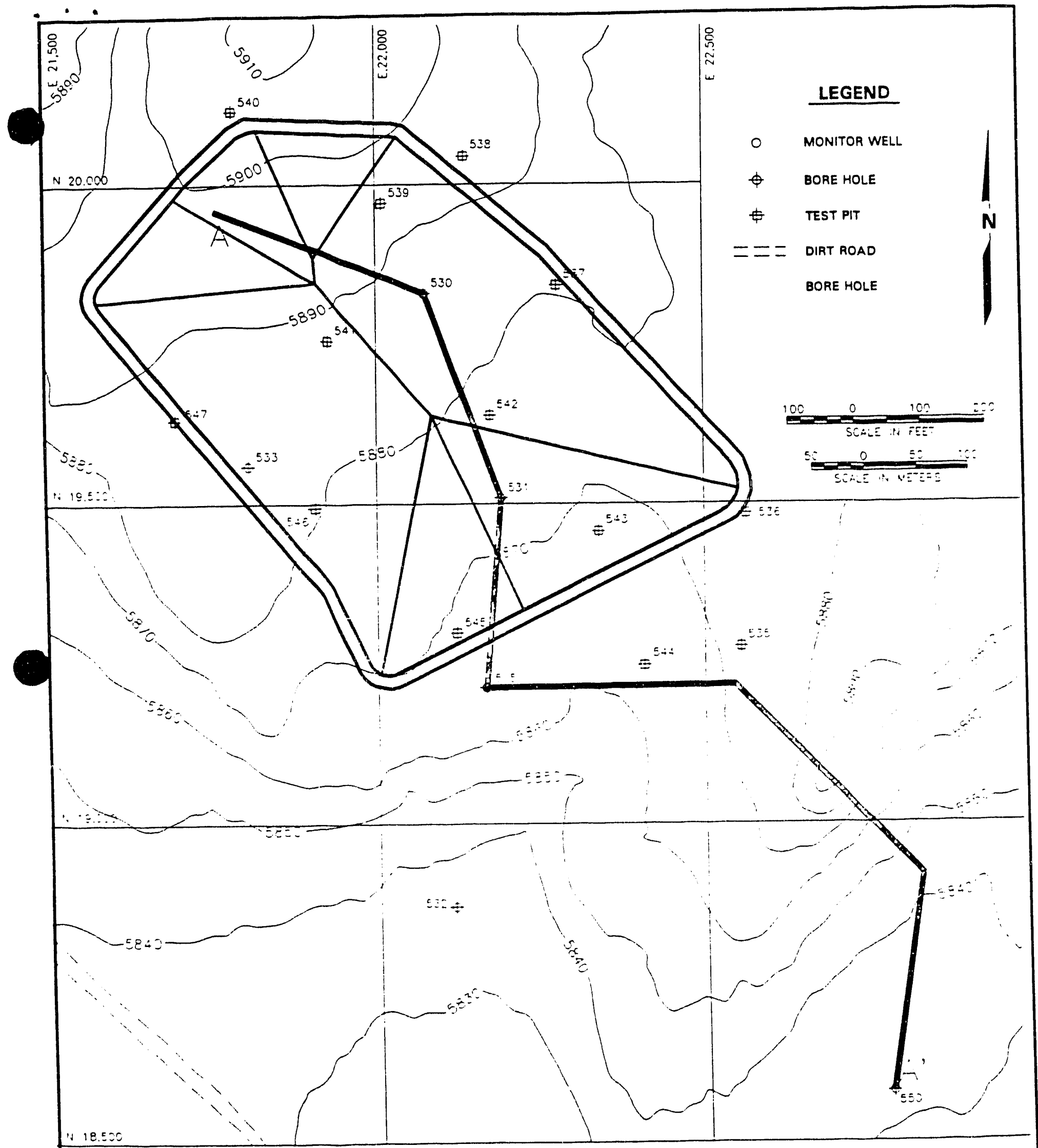

FIGURE $\mathbf{3 . 1 0}$

MONITOR WELL LOCATION MAP AND NORTH-SOUTH (A-A') CROSS SECTION AT THE BURRO CANYON DISPOSAL SITE, COLORADO 


\subsubsection{Geology and hydrostratigraphy}

To characterize the hydrogeology of the site in the Burro Canyon Formation, the DOE installed six monitor wells in the upper sandstone unit, six wells in the middle sandstone unit, and four wells in the lower sandstone unit. Construction information for these monitor wells is summarized in Table 3.41 of Appendix A. Detailed lithologic logs and construction information are presented in Appendix B.

The Burro Canyon disposal site is located on a weathered pediment of Dakota Sandstone that overlies the interbedded mudstones, siltstones, and sandstones of the Burro Canyon Formation. The lowest unit of Dakota Sandstone consists primarily of low-permeability carbonaceous shale and mudstone. Two thin sandstone layers ranging in thickness from 1 to $6 \mathrm{ft}(0.3$ to $2 \mathrm{~m})$ are interbedded with the shales and mudstones in the lower Dakota Sandstone. The Dakota Sandstone is unsaturated in the site vicinity and is therefore not discussed in detail in this Groundwater Hydrology Report. Groundwater beneath the site occurs in the sandstone units of the Burro Cariyon Formation.

The Burro Canyon Formation is relatively uniform in thickness in the vicinity of the site (Shawe et al., 1968). The grade of the Burro Canyon Formation is approximately 3 percent, as discussed in Section 3.1 of Attachment 2. Three water-bearing sandstone units lie beneath the proposed disposal cell. These sandstone units are within the Burro Canyon Formation at approximate depths of 100,200 , and $300 \mathrm{ft}(30,60$, and $90 \mathrm{~m})$, and are described as the upper, middle, and lower units, respectively. They are fine- to medium-grained sandstone layers ranging from 25 to $75 \mathrm{ft}(8$ to $23 \mathrm{~m})$ in thickness and are separated by thick interbedded claystone, mudstone, and siltstone sequences (hereafter referred to as mudstonel, as shown in Figure 3.11. The three sandstone units are hydrogeologically separated from each other, as evidenced by 1) differences in the geology and hydraulic properties of the sandstone versus the mudstone units, 2) differences in potentiometric surfaces for each unit, and 3) differences in the groundwater geochemistry of each unit. The mudstone/claystone units above the upper sandstone unit and between the upper, middle, and lower sandstone units are effective aquitards, inhibiting the potential migration of fluids and contaminants from the area of the proposed disposal cell. Moreover, significant upward vertical hydraulic gradients exist in the middle and lower sandstone units. Therefore, even if seepage from the disposal cell occurred, the upward vertical gradients would prohibit potential seepage from migrating below the upper sandstone unit. The presence and movement of groundwater is discussed in greater detail in Section 3.2.3.

A stratigraphic north-south cross section is provided for the disposal site in Figure 3.11. As indicated on this figure, the thicknesses of the units remain relatively uniform. Groundwater elevations measured in each monitor well at the Burro Canyon disposal site from February 1990 to November 1992 are provided in Table 3.42 of Appendix A. 


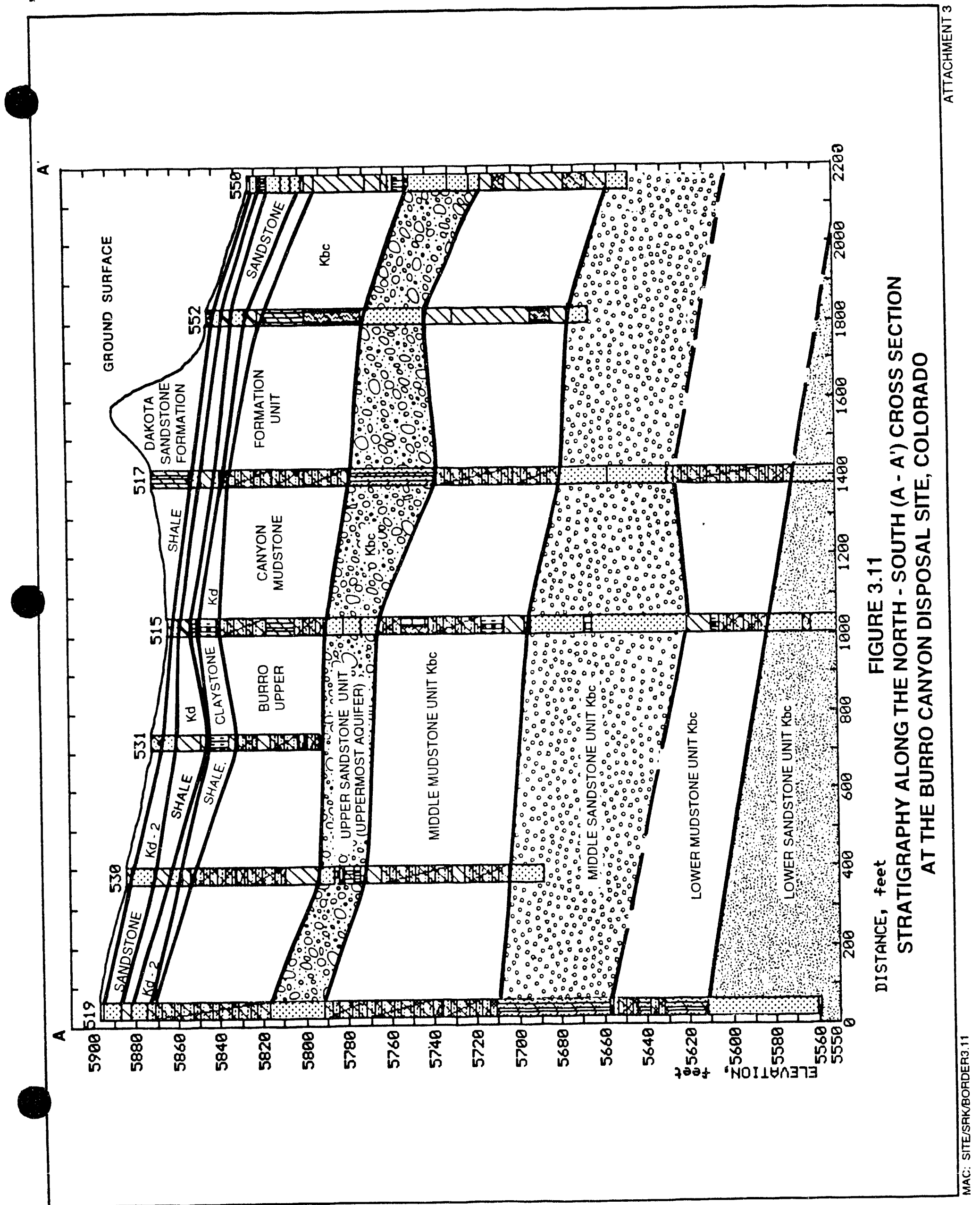




\subsubsection{Presence and movement of groundwater}

\section{Burro Canyon upper sandstone unit}

The upper sandstone unit of the Burro Canyon Formation (including some interbedded mudstone layers) ranges from 20 to $40 \mathrm{ft}(6$ to $12 \mathrm{~m})$ thick beneath the disposal cell footprint, and underlies approximately $50 \mathrm{ft}(15 \mathrm{~m})$ of mudstone. Groundwater occurs under semiconfined conditions and the yield is very low. Groundwater movement is to the southeast, as shown in Figure 3.12. The top of the upper sandstone unit occurs from 77 to $99 \mathrm{ft}(23$ to $30 \mathrm{~m})$ bls. The depth to the water table ranges from 75 to $110 \mathrm{ft}(23$ to $34 \mathrm{~m}) \mathrm{bls}$ in the upper sandstone unit. Figure 3.13 shows that groundwater elevations have remained constant. Recharge to the upper sandstone unit is expected to be from infiltrating the surface outcrop (upgradient of the site). Additional hydraulic information for this unit is provided in Section 3.2.4.

\section{Burro Canyon middle sandstone unit}

The middle sandstone unit ranges from 55 to $75 \mathrm{ft}(17$ to $23 \mathrm{~m})$ thick beneath the site and underlies approximately 60 to $70 \mathrm{ft}(18$ to $21 \mathrm{~m})$ of mudstone. The top of the middle sandstone unit occurs at a depth between 170 and $191 \mathrm{ft} 152$ to $58 \mathrm{~m}$ ) bls in the vicinity of the disposal cell footprint. Groundwater occurs under confined conditions and has an upward hydraulic gradient; the potentiometric surface is approximately $40 \mathrm{ft}(12 \mathrm{~m})$ above the top of the middle sandstone unit. A potentiometric surface contour map of the middle sandstone unit is provided in Figure 3.14. Groundwater flows to the southeast. Groundwater elevations have remained constant, as shown in Figure 3.15. Recharge to the middle sandstone unit occurs upgradient from the disposal cell, approximately 0.25 to $0.75 \mathrm{mi}(0.4$ to $1.2 \mathrm{~km})$ northeast of the site. Sandstone beds outcrop along the east limb of the Disappointment syncline and intercept tributaries to the Nicholas Wash drainage system. Groundwater then flows to the south-southeast and eventually dissipates (discharges) into the surrounding geologic strata of the Burro Canyon Formation south of the Burro Canyon disposal site.

\section{Burro Canyon lower sandstone unit}

The lower water-bearing sandstone unit beneath the disposal cell is $39 \mathrm{ft}(12 \mathrm{~m})$ thick, and the top of the unit is located approximately $305 \mathrm{ft}(93 \mathrm{~m}) \mathrm{bls}$. A potentiometric surface contour map of the lower sandstone unit is provided in Figure 3.16. Groundwater in this unit is confined by the thick sequence of overlying low-permeability mudstones and siltstones of the Burro Canyon Formation. Groundwater has an upward gradient with the potentiometric surface 169 to $240 \mathrm{ft}(52$ to $73 \mathrm{~m})$ above the top of the lower sandstone unit and averaging $52 \mathrm{ft}(16 \mathrm{~m})$ above the middle sandstone unit. The lower sandstone unit has an extremely low velocity and well yield. Groundwater elevations have remained constant, as shown in Figure 3.17. Vertical recharge to and discharge from the lower sandstone unit is restricted because the low-permeability interbedded claystone and siltstone strata impede infiltration. 


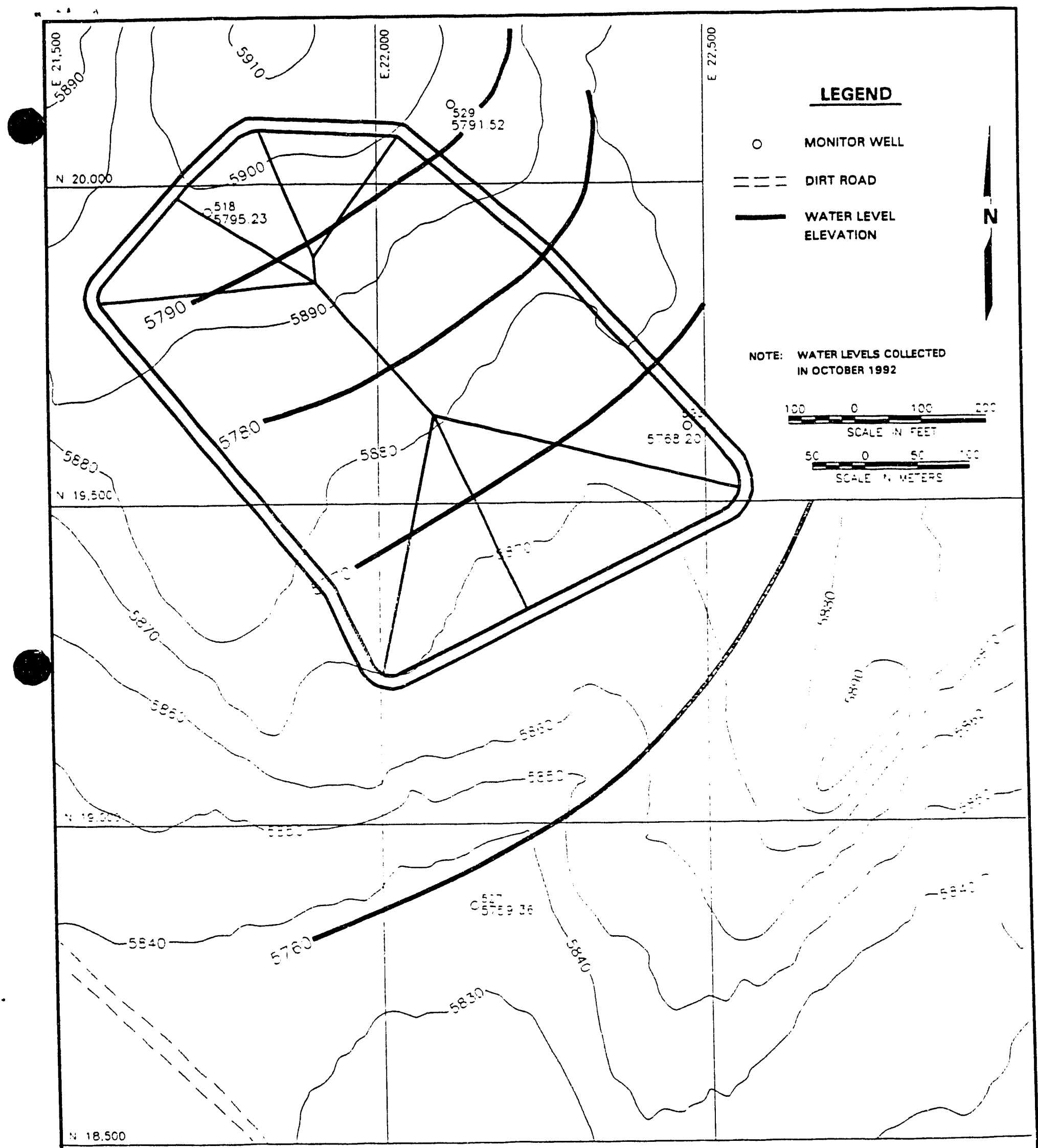

FIGURE $\mathbf{3 . 1 2}$

POTENTIOMETRIC SURFACE CONTOUR MAP OF THE BURRO CANYON UPPER SANDSTONE UNIT AT THE BURRO CANYON DISPOSAL SITE, COLORADO 


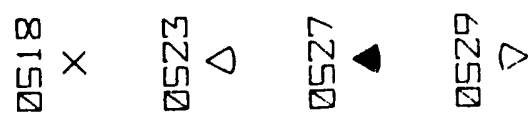
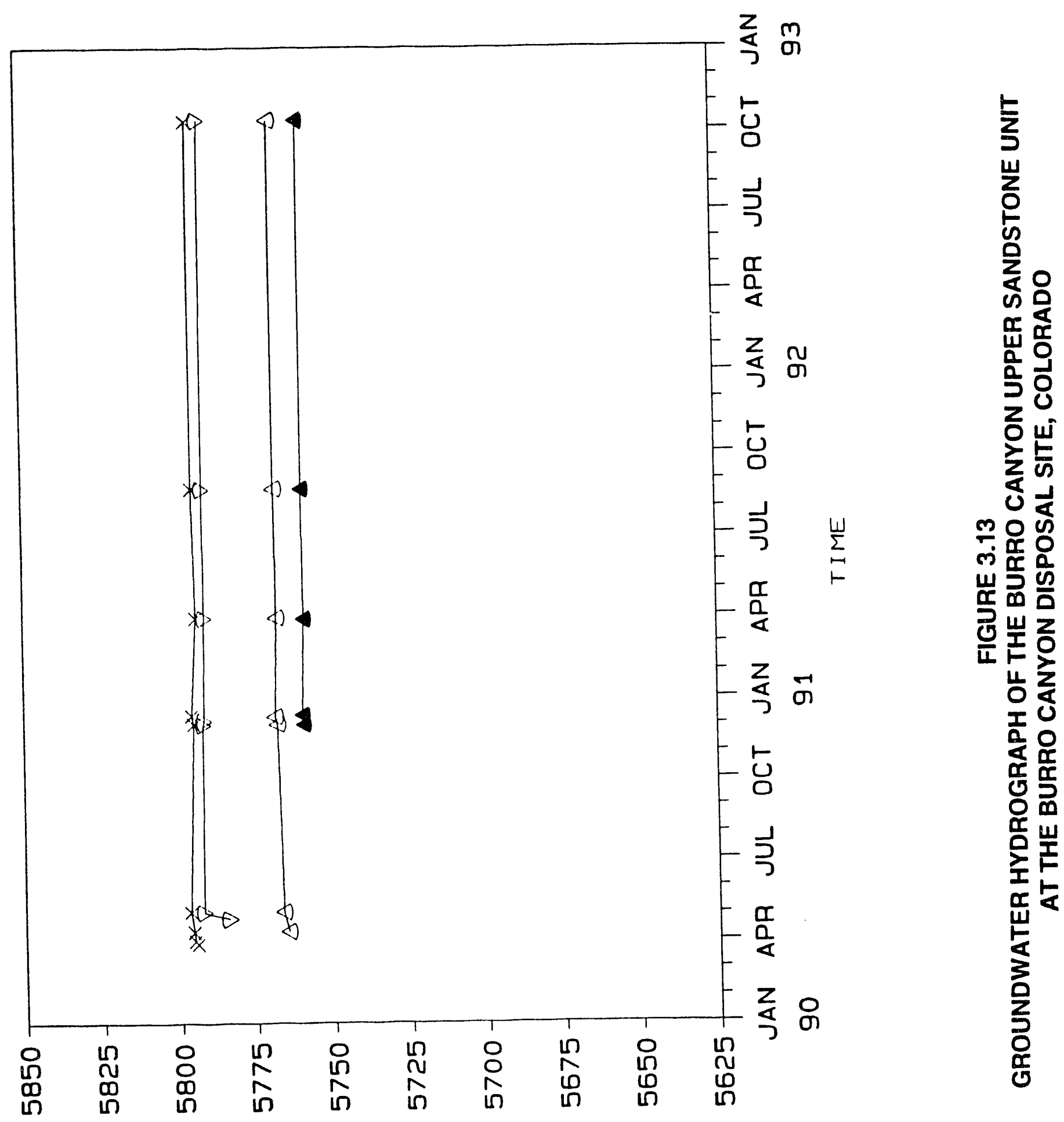

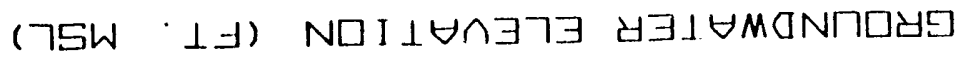




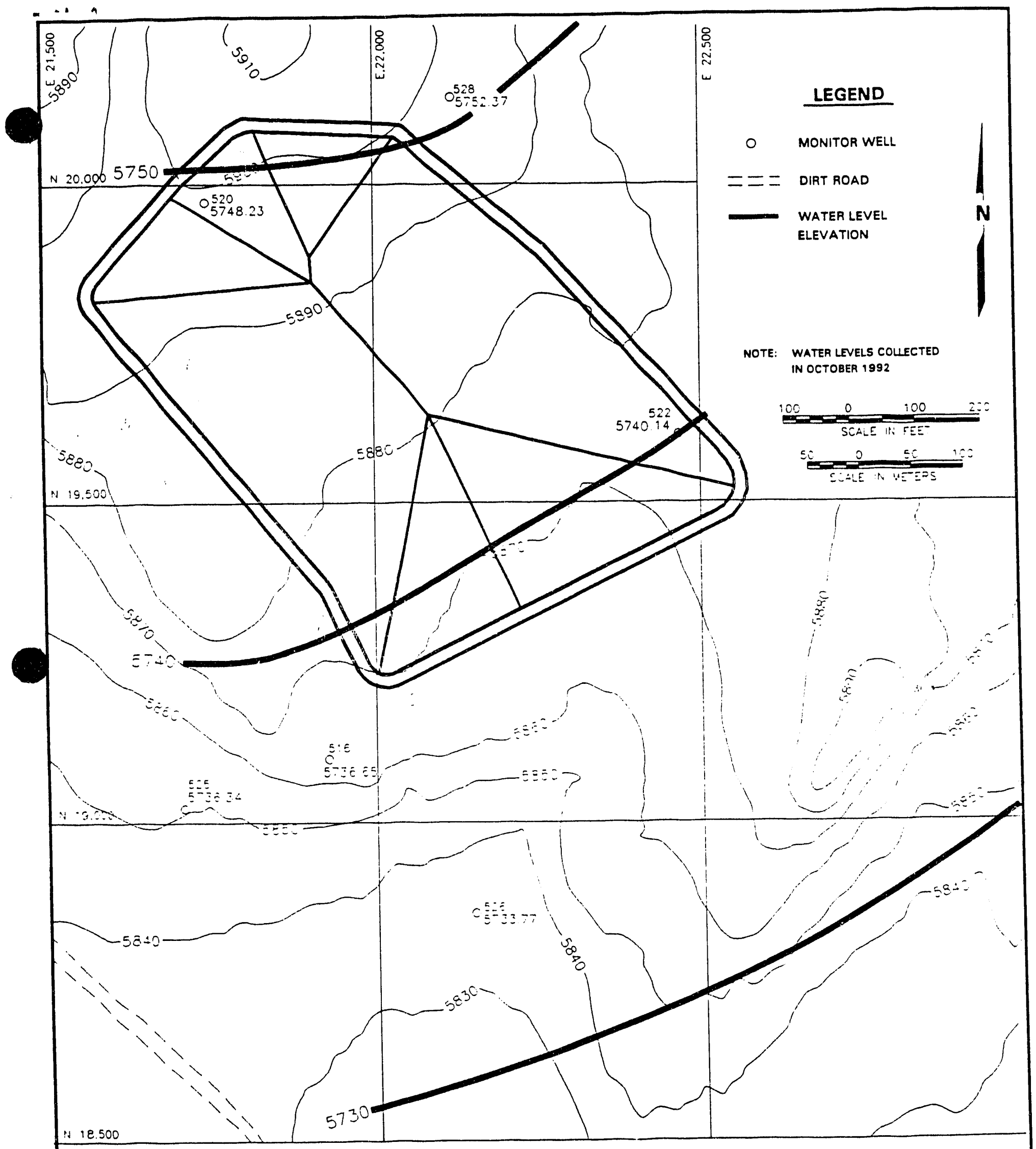

FIGURE 3.14

POTENTIOMETRIC SURFACE CONTOUR MAP OF THE BURRO CANYON MIDDLE SANDSTONE UNIT AT THE BURRO CANYON DISPOSAL SITE, COLORADO 


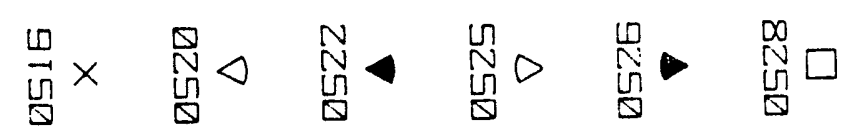
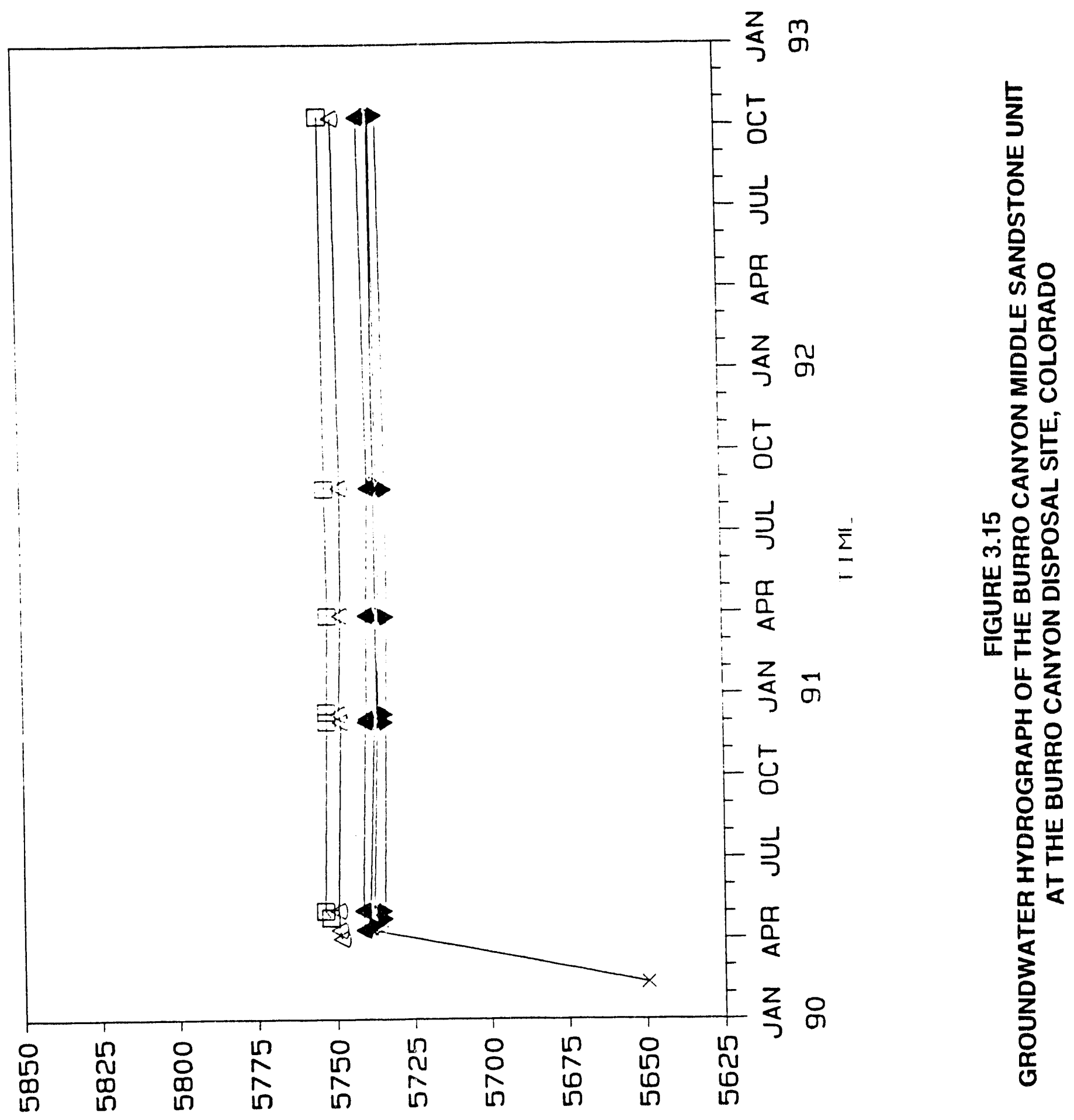

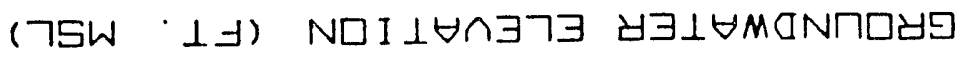




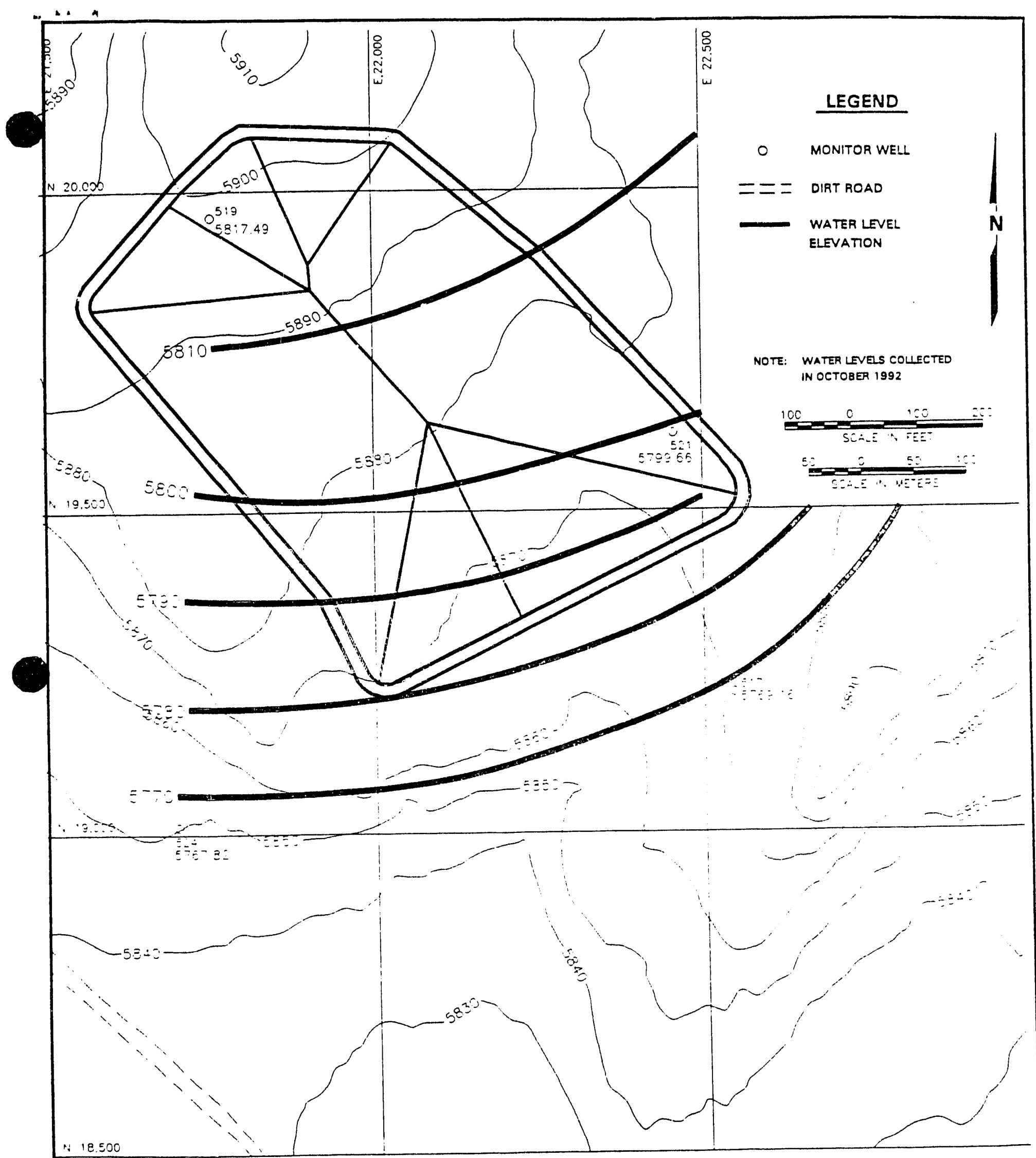

FIGURE 3.16

POTENTIOMETRIC SURFACE CONTOUR MAP OF THE BURRO CANYON LOWER SANDSTONE UNIT AT THE BURRO CANYON DISPOSAL SITE, COLORADO 


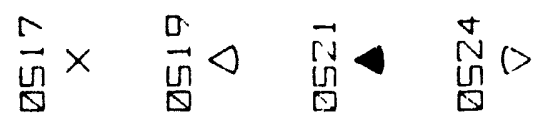
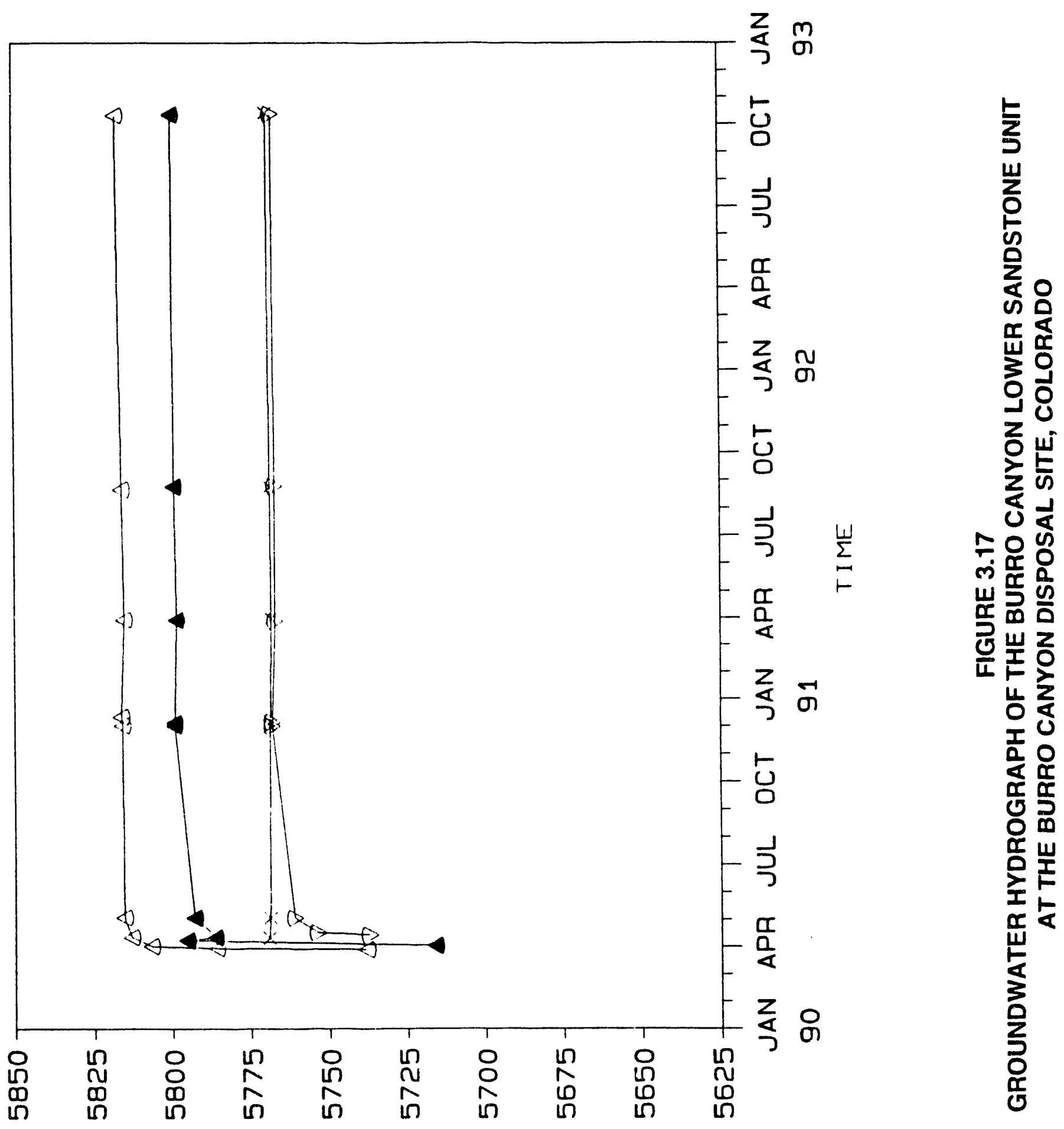

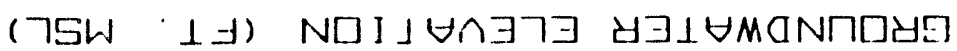




\subsubsection{Hydraulic characteristics}

Table 3.43 of Appendix A presents the average aquifer parameters and average linear groundwater velocities in each water-bearing unit of the Burro Canyon Formation. Calculations of average hydraulic gradients and average groundwater velocities are presented in Calculation SRK-05-93-14-06-00 in Appendix $C$. Analyses for aquifer performance and slug tests are presented in Calculation SRK-06-91-14-03-00 in Appendix C.

\section{Unsaturated Dakipta Sandstone and Burro Canyon Formations}

The hydraulic conductivity of the unsaturated Dakota Sandstone bedrock and unsaturated Burro Canyon Formation mudstones was determined by field packer tests. A total of 16 packer tests was conducted in three coreholes at selected depths to measure the hydraulic conductivity of the bedrock. The tests were analyzed using the approach outlined in the U.S. Bureau of Reclamation's Earth Manual (USBR, 1974), and the results are summarized in Table 3.43 of Appendix $A$. The average horizontal hydraulic conductivity of the lower Dakota Sandstone Formation was $4.3 \times 10^{-1} \mathrm{ft} /$ day $\left(1.5 \times 10^{.4} \mathrm{~cm} / \mathrm{s}\right)$, and the average horizontal hydraulic conductivity of the mudstones in the Burro Canyon Formation was estimated to be $6.5 \times 10^{.3} \mathrm{ft} /$ day $\left(2.3 \times 10^{.6} \mathrm{~cm} / \mathrm{s}\right)$. Packer tests indicate that the saturated horizontal hydraulic conductivity of the sandstone in the Dakota Formation is moderate, and is several orders of magnitude greater than that of the Burro Canyon Formation. In addition, the hydraulic conductivity decreases with depth in the Burro Canyon mudstone, reflecting decreased fracture permeability with depth.

\section{Burro Canyon upper sandstone unit}

To determine the hydraulic properties of the upper sandstone unit, low-yield aquifer performance pumping tests were conducted on monitor wells 523 and 529; bailer recovery tests were conducted on monitor wells 518 and 527 . Monitor well 523 was pumped at an average rate of 0.13 gallons per minute $(\mathrm{gpm})$ (the lowest possible pumping rate to approximate $150 \mathrm{gpd})\left(7 \times 10^{-3} \mathrm{~L} / \mathrm{s}\right)$ for 39 hours (hr). Substantial drawdown 61 percent of the available drawdown) occurred during the aquifer performance pumping test. The pumping rate was increased to $0.5 \mathrm{gpm}\left(8 \times 10^{.3} \mathrm{~L} / \mathrm{s}\right)$ to determine if the well could support a higher pumping rate; however, the well went dry. In a second pumping test, monitor well 529 was pumped at a rate of $0.13 \mathrm{gpm}$ $\left(8 \times 10^{3} \mathrm{~L} / \mathrm{s}\right)$, and went dry within $2 \mathrm{hr}$. During both pumping tests, no response was observed in nearby monitor wells completed in the upper and middle sandstone units. Bailer recovery tests conducted on the upper sandstone unit indicated that the transmissivity ranges from $0.022 \mathrm{ft}^{2} / \mathrm{day}$ to $1.04 \mathrm{ft}^{2} / \mathrm{day}$ $\left[2.2 \times 10^{.8}\right.$ square meters $\left(\mathrm{m}^{2}\right) / \mathrm{s}$ to $\left.1.1 \times 10^{6} \mathrm{~m}^{2} / \mathrm{s}\right]$, and averages $0.16 \mathrm{ft}^{2} / \mathrm{day}$ $\left(1.7 \times 10^{.7} \mathrm{~m}^{2} / \mathrm{s}\right)$. However, borehole storage effects are believed to be significant and the aquifer may not have been stressed. The average hydraulic conductivity of the upper sandstone unit is $4 \times 10^{2} \mathrm{ft} /$ day $\left(1 \times 10^{.5} \mathrm{~cm} / \mathrm{s}\right)$. The 
results of these tests are presented in Calculation SRK-08-91-14-03-01 in Appendix C.

Darcy's Law was used to calculate the average linear groundwater velocity in the upper sandstone unit of the Burro Canyon Formation (Calculation SRK-05-93-14-00, Appendix $C$ ). The average linear groundwater velocity in the upper sandstone unit was estimated to be $5.5 \mathrm{ft} / \mathrm{yr}\left(5.3 \times 10^{.6} \mathrm{~cm} / \mathrm{s}\right)$ (Table 3.43 of Appendix A), based on an average hydraulic conductivity of $4 x$ $10^{.2} \mathrm{ft} /$ day $\left(1 \times 10^{.5} \mathrm{~cm} / \mathrm{s}\right)$, a hydraulic gradient of 0.038 , and an effective porosity of 0.10 (Freeze and Cherry, 1979).

The upper sandstone unit has a low transmissivity and an average saturated thickness of $12 \mathrm{ft}(4 \mathrm{~m})$. A numerical simulation of a hypothetical well completed in the upper unit suggests that even assuming a transmissivity of $1.04 \mathrm{ft}^{2} /$ day and a saturated thickness of $19 \mathrm{ft}(5.8 \mathrm{~m})$, this unit cannot sustain a minimum yield of $150 \mathrm{gpd}$. Because of the demonstrated low yield from the aquifer (less than $150 \mathrm{gpd}$ ), groundwater is classified as Class 111 (limited use), in accordance with 40 CFR 192.11 (e) of the proposed EPA groundwater standards.

\section{Burro Canyon middle sandstone unit}

To determine the aquifer parameters of the middle unit and the degree of hydraulic connection with the upper and lower units, a 72-hour pumping test was conducted on monitor well 522; drawdown and recovery were observed in all six other monitor wells completed in the middle unit. Monitor well 522 was pumped at an average rate of $0.5 \mathrm{gpm}\left(3 \times 10^{.2} \mathrm{~L} / \mathrm{s}\right)$ for the entire duration of the test; a preliminary step test indicated the well could not support a pumping rate of $1 \mathrm{gpm}\left(6 \times 10^{2} \mathrm{~L} / \mathrm{s}\right)$ because of excessive drawdown.

The pumping and recovery tests on the middle unit indicated that the transmissivity of the aquifer ranges from 5 to $7 \mathrm{ft}^{2} /$ day $\left(5\right.$ to $7 \times 10^{6} \mathrm{~m}^{2} / \mathrm{s}$ ), and averages $6 \mathrm{ft}^{2} /$ day $\left(6 \times 10^{6} \mathrm{~m}^{2} / \mathrm{s}\right.$ ) (Table 3.43 of Appendix A). During the $72-\mathrm{hr}$ test, responses were noted in five observation wells screened in the middle sandstone unit. However, no responses were observed in the upper or lower water-bearing units.

The average hydraulic conductivity of the middle sandstone unit is $9 \times 10^{.2} \mathrm{ft} /$ day $\left(3 \times 10^{.5} \mathrm{~cm} / \mathrm{s}\right)$, assuming an average saturated thickness of $65 \mathrm{ft}(20 \mathrm{~m})$. The average linear groundwater velocity in the middle sandstone unit is $2.5 \mathrm{ft} / \mathrm{yr}$ (Table 3.43 of Appendix A), assuming an average hydraulic conductivity of $9 \times 10^{.2} \mathrm{ft} /$ day $\left(3 \times 10^{.5} \mathrm{~cm} / \mathrm{s}\right)$, a hydraulic gradient of 0.015 . and an effective porosity of 0.20 (Freeze and Cherry, 1979).

The confined conditions in this unit cause a substantial upward hydraulic potential. The potentiometric surface of the middle unit averages $42 \mathrm{ft}(13 \mathrm{~m})$ above the top of the sandstone unit. This potentiometric surface, however, is not higher in elevation than the overlying potentiometric surface measured in 
monitor wells screened in the upper sandstone unit. Calculations are documented in Appendix $C$ (Calculations SRK-05-93-14-00-01 and SRK-05-9314-06-001.

\section{Burro Canyon lower sandstone unit}

Slug injection tests conducted on monitor wells 519, 521, and 524 completed in the lower sandstone unit indicate that the unit transmissivity averages $0.1 \mathrm{ft}^{2} /$ day $\left(1 \times 10^{-7} \mathrm{~m} / \mathrm{s}\right)$ (Table 3.43 of Appendix A). However, borehole effects are likely to be significant. As a result, transmissivity values may be biased by borehole stage effects. The average hydraulic conductivity of the lowermost unit is $5 \times 10^{.3} \mathrm{ft} /$ day $\left(2 \times 10^{.6} \mathrm{~cm} / \mathrm{s}\right)$. The average linear groundwater velocity in the lower sandstone unit is $1 \mathrm{ft} / \mathrm{yr}\left(1 \times 10^{.6} \mathrm{~m} / \mathrm{s}\right)$, assuming a hydraulic conductivity of $5 \times 10^{-3} \mathrm{ft} / \mathrm{day}\left(2 \times 10^{.6} \mathrm{~cm} / \mathrm{s}\right)$, a gradient of 0.057 , and an effective porosity of 0.10 (Table 3.43 of Appendix A). Calculations are documented in Appendix $C$ (Calculations SRK-05-93-14-06-00 and SRK-08-91-14-03-011.

\subsubsection{Background groundwater quality}

Background groundwater quality in each hydrostratigraphic unit within the Burro Canyon Formation was determined from analyses of groundwater from monitor wells completed in each unit. Groundwater quality data were characterized individually for each hydrostratigraphic unit because the units are hydrogeologically separated (Calculation SRK-05-93-12-10-00 in Appendix C.

In general, groundwater $\mathrm{pH}$ is near neutral, and TDS concentrations tend to decrease with depth. The average TDS concentration is $751 \mathrm{mg} / \mathrm{L}$ in the upper sandstone unit, $577 \mathrm{mg} / \mathrm{L}$ in the middle sandstone unit, and $335 \mathrm{mg} / \mathrm{L}$ in the lower sandstone unit.

\section{Burro Canyon upper sandstone unit}

Six background groundwater monitor wells are screened and filter-packed into the upper sandstone unit of the Burro Canyon Formation. These monitor wells are identified as 518,523,527,529,551, and 552 in Figure 3.11. Groundwater quality data by parameter are provided in Table 3.44 of Appendix A. Groundwater quality statistics are provided in Table 3.45 and summarized in Table 3.46 of Appendix A.

Groundwaters in this unit are sodium sulfate and sodium bicarbonate types. TDS concentrations range from $598 \mathrm{mg} / \mathrm{L}$ to $945 \mathrm{mg} / \mathrm{L}$. Groundwater in the upper sandstone unit is neutral to slightly alkaline with pH ranging from 7.5 to 9.1 .

As shown in Table 3.47 of Appendix A, the activity of Ra-226 and -228 has equaled or slightly exceeded its $\mathrm{MCL}$ on one occasion in samples collected from monitor wells 518 and 529. In addition, the concentration of selenium 
consistently exceeds the MCLs in groundwater samples collected from monitor well 518.

\section{Burro Canyon middle sandstone unit}

Six background groundwater monitor wells are screened and filter-packed into the middle sandstone unit of the Burro Canyon Formation. These monitor wells are identified as 516,520,522,525,526, and 528 in Figure 3.11 . Groundwater quality data by parameter are provided in Table 3.48 of Appendix A. Groundwater quality statistics are provided in Table 3.49 of Appendix A.

Monitor wells screened in the middle sandstone unit produce groundwaters that are characterized as sodium bicarbonate and sodium sulfate types; the $\mathrm{pH}$ ranges from 7.2 to 7.6 . TDS concentrations range from $460 \mathrm{mg} / \mathrm{L}$ to $658 \mathrm{mg} / \mathrm{L}$. The activity of Ra-226 and -228 slightly exceeded its MCL in one well $(516)$ in a one-time occurrence (Table 3.50 of Appendix A).

\section{Burro Canyon lower sandstone unit}

Four background groundwater monitor wells are screened and filter-packed into the lower sandstone unit of the Burro Canyon Formation. These monitor wells are identified as $517,519,521$, and 524 in Figure 3.11. Groundwater quality data by parameter are provided in Table 3.51 of Appendix A. Groundwater quality statistics are provided in Table 3.52 of Appendix $A$.

Groundwater samples collected from monitor wells screened in the lower sandstone unit are of the sodium bicarbonate type. TDS concentrations range from $281 \mathrm{mg} / \mathrm{L}$ to $336 \mathrm{mg} / \mathrm{L}$. The ground water of the lower sandstone unit is slightly alkaline, with $\mathrm{pH}$ ranging from 8.6 to 9.6. All water-quality samples collected from monitor wells screened in the lower unit have been below the MCLs for all regulated constituents.

\section{Geochemical conditions}

Favorable geochemical conditions appear to be present at the Burro Canyon disposal site for attenuation of most hazardous constituents present in the tailings pore fluid. This assessment is based on chemical analyses of the drill cuttings and cores (including chemical analyses, polarized light microscopy with modal analyses, screen analyses, and $X$-ray diffraction), groundwater quality analyses, examination of the stratigraphic section of the geologic materials underlying the proposed disposal site, and preliminary laboratory experiments.

Geochemical conditions that control the transport of the hazardous constituents from the tailings into groundwater and by groundwater within the aquifers at the disposal site are essentially the same as the conditions controlling transport at the processing site. These conditions include 1) the groundwater chemical composition, $\mathrm{pH}$, and $\mathrm{Eh}$ of the tailings pore fluid, soil pore fluid, and 
groundwater; and 2) the reactive mineralogy of the subsoils and aquifer materials. The chemical compositions, $\mathrm{pH}$, and Eh of the various fluids determine the types of precipitation/coprecipitation reactions that can occur to control the migration rate of contaminants of concern. The chemical compositions, $\mathrm{pH}$, and Eh of the fluids combined with the reactive mineralogy of the subsoils and aquifer materials determine the sorts of adsorption reactions that can involve contaminants of concern.

Precipitation and coprecipitation reactions can result from acid-neutralization reactions, a general condition of oversaturation in the tailings seepage, and oxidation-reduction reactions. The acid-neutralization reactions occur as a result of the tailings leachate seepage into subsurface units that contain carbonates and other acid-neutralizing phases. Neutralization of acid leachate causes the precipitation of alkali earth and transition metals originally in the leachate. Because the tailings fluids at the UC and NC sites are near-neutral in pH 16.2 to 7.8), acid-neutralization reactions will not be a major retardation mechanism for the contaminants of concern at the processing site. However, even if acid conditions were present, the high calcite content $\left(36\right.$ tons $\mathrm{CaCO}_{3} / 1000$ tons soil) (PMET, 1990) of the Burro Canyon shale beneath the cell would neutralize the acid.

The tailings pore fluids are generally oversaturated in gypsum, calcite, quartz, and, locally, in other solid phases. Although such oversaturation eventually leads to precipitation, the precipitation reactions are commonly slow to occur. In general, quartz precipitation rates are much slower than gypsum rates at the same level of oversaturation. Therefore, gypsum tends to precipitate from oversaturated solutions before quartz. As these phases precipitate in the pore spaces in the tailings within the cell or in the rock units beneath the cell, some trace contaminants of concern may coprecipitate with them, depending on the saturation level of the contaminant species. For example, radium could precipitate with gypsum or barite and cadmium and zinc could coprecipitate with calcite.

The oxidation-reduction induced precipitation reactions are probably the most important class of precipitation reactions at the disposal and processing sites for the same reasons. The Eh and several related parameters were measured in most wells screened in the middle and lower sandstone units at the Burro Canyon disposal site. Wells in the upper sandstone unit did not vield sufficient quantities of water to allow measurement of Eh or related parameters. In general, wells screened in the lower sandstone unit had relatively high Eh values $(400 \mathrm{mV})$ indicative of oxidizing conditions. Wells in the middle sandstone unit showed a range in Eh from 200 to $400 \mathrm{mV}$. Beneath the footprint of the cell, the values ranged from 200 to $330 \mathrm{mV}$ with a average value of $250 \mathrm{mV}$. This value is not sufficiently reducing to convert sulfate to sulfide or $U^{+6}$ to $U^{+4}$. However, it would result in ammonium being the dominant nitrogen species and native selenium being the dominant form of selenium. Ammonium and native selenium are less mobile than their corresponding oxidized forms. The Burro Canyon mudstone unit directly beneath the cell contains finely disseminated 
pyrite that may locally provide sufficiently reducing conditions to convert $U^{+6}$ to $U^{+4}$, at least on the pyrite grain surfaces.

Adsorption reactions involve the attachment of simple and complex ions to the exterior surfaces of minerals and/or ion exchange on interior exchange sites in ion exchanging minerals. Although the details of the surface attachment reactions are not completely known, it is well known that surfaces of iron and manganese oxides and oxyhydroxides have high affinities for transition metals and oxyanions at neutral to somewhat acidic conditions. However, the metals and oxyanions do not all have the same affinity for these oxides and oxyhydroxides. On the basis of theoretical derivations, the relative affinities cannot be reliably predicted in complex natural systems such as the groundwater systems associated with uranium mill tailings sites. These relative affinities must be measured in a laboratory by either batch or column experiments.

Ion exchange reactions involving cations are better understood. The (cation) ion exchange capacities of the upper Burro Canyon mudstone are relatively high 115 to 16 milliequivalents (meq)/100 grams $(\mathrm{g})$ ) with the ion exchange capacity of the upper sandstone unit being somewhat lower at $6.6 \mathrm{meq} / 100 \mathrm{~g}$. These data suggest a significant exchange capacity exists in the units directly beneath the cell. However, the relative affinities of the ion exchanging mineral phases (e.g., clays) for specific cationic contaminants such as radium, cadmium, and zinc must be determined experimentally in batch and/or column experiments.

The results of preliminary laboratory experiments suggest cadmium has a large affinity for the Burro Canyon mudstone unit [distribution coeffient $\left(K_{d}\right)=$ $900 \mathrm{~mL} / \mathrm{g}$ ] while uranium and molybdenum have small affinities $\left(K_{d}\right.$ of approximately $0.5 \mathrm{~mL} / \mathrm{g}$ ).

\subsubsection{Groundwater use, value, and alternative supplies}

No known registered wells or private wells are actively used within the upper sandstone unit of the Burro Canyon Formation within a $2-\mathrm{mi}(3-\mathrm{km})$ radius of the Burro Canyon disposal site.

Groundwater development in the vicinity of the disposal site should not increase over the next 50 years. The first hydrostratigraphic zone of saturation has a low yield (less than $150 \mathrm{gpd}$ ), and is therefore classified as Class III (limited use) in accordance with Part 4O CFR 192.11(e) of the EFA groundwater protection standards. By definition, Class III groundwater is not a current or potential source of drinking water.

No development is planned adjacent to the proposed Burro Canyon disposal site. 


\subsection{REFERENCES}

Cooley et al. (M. E. Cooley, J. W. Hershbarger, J. P. Akers, and W. E. Hardt), 1969. "Regional Hydrogeology of the Navajo and Hopi Indian Reservations, Arizona, New Mexico, and Utah," U.S. Geological Survey Professional Paper 521-A, Washington, D.C.

Daniel B. Stephens \& Associates, Inc., 1991. Laboratory Analysis of Soil Hydraulic Properties of the Burro Canyon Rock Samples, prepared for the U.S. Department of Energy, UMTRA Project Office, Albuquerque Operations Office, Albuquerque, New Mexico.

DOE (U.S. Department of Energy), 1992. Software Program for Environmental Analysis and Reporting (SPEAR) System, DOE UMTRA Project Office, Albuquerque Operations Office, Albuquerque, New Mexico.

DOE (U.S. Department of Energy), 1989. Technical Approach Document, UMTRA-DOE/AL-050425.0002, DOE UMTRA Project Office, Albuquerque Operations Office, Albuquerque, New Mexico.

DOE (U.S. Department of Energy), 1986. Comparative Analysis of Disposal Site Alternatives Report for the UMTRA Project Slick Rock Site Located at Slick Rock, Colorado, DOE UMTRA Project Office, Albuquerque Operations Office, Albuquerque, New Mexico.

EPA (U.S. Environmental Protection Agency), 1989. Statistical Analysis of Ground-Water Monitoring Data at RCRA Facilities - Interim Final Guidance, EPA/530-SW-89026.

EPA (U.S. Environmental Protection Agency), 1987. Standards for Remdial Actions at Inactive Uranium Processing Sites: Proposed Rule, 40 CFR 192, 52 Federal Register 36000, September 24, 1987.

FBDU (Ford, Bacon \& Davis Utah Inc.), 1981. Engineering Assessment of Inactive Uranium Mill Tailings, Slick Rock Sites, Slick Rock, Colorado, DOE/UMT-0115, FBDU 360-07, UC 70, prepared by FBDU, Salt Lake City, Utah, for the U.S. Department of Energy, UMTRA Project Office, Albuquerque Operations Office, Albuquerque, New Mexico.

FBDU (Ford, Bacon \& Davis Utah Inc.), 1977. "Engineering Assessment of the Inactive Uranium Mill Tailings, Slick Rock, Colorado, DOE/UMT-0115, prepared by FBDU, Salt Lake City, Utah, for the U.S. Department of Energy, Albuquerque Operations Office, Albuquerque, New Mexico.

Freeze, R. A., and J. A. Cherry, 1979. Ground Water, Prentice-Hall, Inc., Englewood Cliffs, New Jersey. 
Merritt, R. C., 1971. The Extractive Metallurgy of Uranium, Colorado School of Mines Research Center, Golden, Colorado.

PMET (Pittsburg Minerai \& Environmental Technology, Inc.), 1990. Chemical and Mineralogical Characterization of Soil Samples from Slick Rock, Colorado iBurro Canyon), prepared by Wolfgang Baum of PME ( for Jacobs Engineering Group Inc., Albuquerque Operations Oifise, Albuquerque, New Mexico.

Shawe et al. (D. R. Shawe, G. C. Simmons, and N. L. Archibold), 1968. Stratigraphy of Slick Rock District and Vicinity, San Miguel and Dulores Counties, Colorado, U.S. Geological Surve; Professiunal Faper 576-A, Washington, D.C.

USBR (U.S. Bureau of Reclamation), 1974. Earth Manual, second edition, Denver, Colorado.

\section{CODE OF FEDERAL :HEGULATIONS}

40 CFR 192, "Health and Environmental Protection Standards for Jranium and Thorium Mill Tailings," Code of Federal Regulations, Vol. 10 , Part 192, U.S. Environmental Protection Agency, Ofíce of the Federal Register, National Archives and Records Administration, Washington, D.C.

\section{PUBLIC LAWS}

PL 95-604 (Public Law 95-604), 1978. Uranium Mill Tailings Radiation Control Act of 1978, 42 USC 7901, November 8, 1978, 95th Congress of the United States of America, Washington, D.C. 

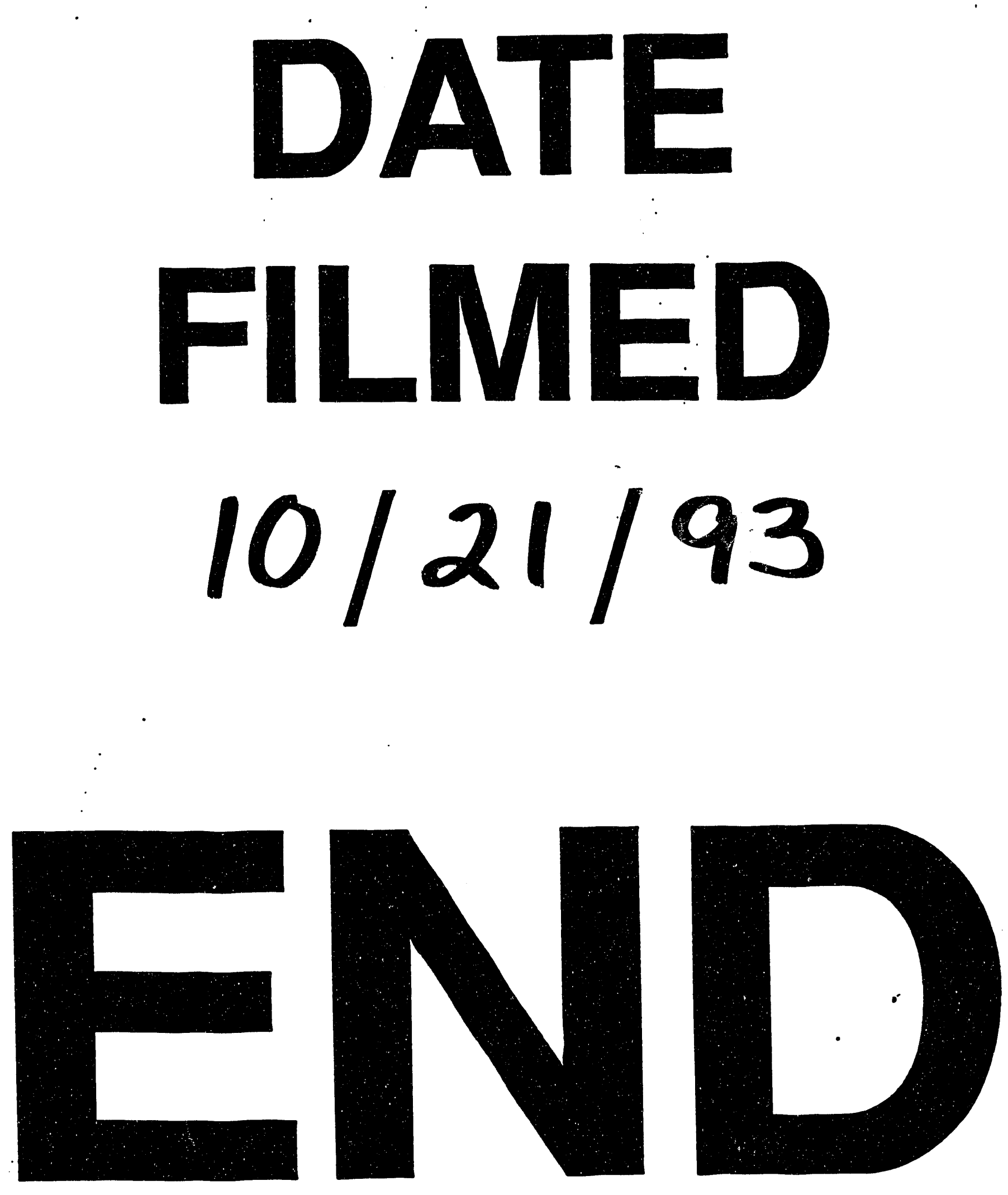
